\title{
Narcissism Over Ideology: Revealed versus Stated Terrorist Preferences*
}

\author{
Kweku A. Opoku-Agyemang ${ }^{\dagger}$
}

\begin{abstract}
What preferences motivate the severity of terrorist attacks? I investigate how Boko Haram terrorists adjust their fatalities when unexpectedly deprived of public attention, relative to $\mathrm{Al}$ Shabaab terrorists, that were not deprived of public attention. Losing public attention raises the severity of terrorism: Boko Haram terrorist fatalities surged following the rebasing of Nigeria's economy, which catapulted the country into Africa's largest and the top twenty-five worldwide. The largest spike in Boko Haram terrorist fatalities occurred in the wake of the Nigerian Ebola health crisis. Although Boko Haram claims an anti-education sentiment, their fatalities do not actually differ significantly from Al Shabaab fatalities during the Nigerian national basic education examination. Overall, terrorists consider well-being changes as threats that have more validity than the persuasiveness of their own claimed ideologies. Terrorist groups do not significantly vary the severity of their attacks during Ramadan. Emphasizing revealed preferences may undermine terrorist credibility and recruitment.
\end{abstract}

Keywords: Violence, terrorism, narcissism, egotism, attention.

\footnotetext{
*This research was funded by the National Science Foundation under Grant No. IIS-1054332. I thank Clionadh Raleigh, Andrew Linke, Håvard Hegre, Joakim Karlsen, and the Armed Conflict Location \& Event Data Project for data availability. I also thank Victor Okorie and Adedoyin Ogunfeyimi for encouragement and helpful conversations that helped the paper. The usual disclaimer applies.

${ }^{\dagger}$ Center for Effective Global Action, University of California at Berkeley, International Growth Centre of London School of Economics and Cornell Tech. Email: kweku@berkeley.edu
} 


\section{Introduction}

The growing use of social media and the internet to radicalize prospective terrorists in the Middle East has attracted significant attention. Unlike the armed conflicts of times past, the general public may appear to have a clearer window into the motivations of terrorists, which are self-reported to be religious. However, given that many religious pracitioners in the same region are victims of terrorism, such motivations of extremists may ultimately be dubious.

The case of terrorists in the Middle East is hardly unique. Terrorists in Africa, such as Boko Haram in Nigeria and Al Shabaab in Somalia claim to have ideological motivations. Boko Haram appears to have a relatively fundamental ideological identity embedded in its very name, which means "Western education is evil." These militant groups have made reported alliances with extremist groups in the Middle East, a point of growing concern for some policy makers.

This paper investigates whether the stated preferences of terrorists align with their revealed preferences. An improved understanding of terrorist motivations may weaken the credibility of such violent groups and lessen recruitment online and offline over time. Also such an approach may foster efficiency in allocating scarce resources in counter-terrorism efforts. Scholars have called for an incentive-based perspective to the roots of terrorism (Krueger, 2007), whereas others (Marchal, 2009; Adeoji 2010) emphasize the role of understanding ideology.

In this paper, I bring a systematic approach to this debate. The perspective of this paper is that relative to stated ideological preferences, Boko Haram terrorists thrive on attention, in the vein of narcissists in psychology and behavioral science. Simon (1971) presciently noted the "poverty of attention" created when a person is overcome by abundant information (as per the internet age). In this paper, I ask a broadly related question: how do violent agents react to a broader kind of attention poverty-when they lose attention? Is this demand for attention more or less important than the claimed ideologies of terrorists? To explore this question, I first investigate how Boko Haram fatalities vary when the terrorist is exposed to a number of (what I shall call) attention shocks, relative to the unexposed Al Shabaab. The advantage of focusing on fatalities relative to terrorist attacks is that they may be a better guage of how intensely the terrorists are influenced by a particular motivation. On the other hand, terrorist attacks may confound fatal attacks with the destruction of 
property, which is distinct. As such, variations in terrorist fatalities are a potentially better way to explain terrorist preferences.

In fact, terrorist fatalities are increasingly used by think tanks in fact sheets to draw attention to terrorism (National Consortium for the Study of Terrorism and Responses to Terrorism, 2015). Following the 2015 mass shooting in Oregon for example, the White House called for quantitative comparisons between the number of Americans killed through terrorist attacks and the number of Americans who have been killed by gun violence (White House Office of the Press Secretary, 2015). Further, several journalists increasingly mention the number of deaths in terrorist attacks to make comparisons about the severity and intensity of an attack For example, although attacks conducted the ISIS terrorist group may receive more global attention, Boko Haram causes significantly more fatalities (Huffington Post, 2017).

To investigate terrorists' preferences with respect to fatalities, I analyze the connections between various phenomena that divert attention from terrorism in Nigeria (relative to Somalia) and terrorist fatalities. I provide strongly suggestive evidence that since 2012, an exaggerated desire to monopolize attention have driven the severity of terrorist murders. Curiously, fatalities spike particularly during the rebasing of Nigeria's economy, a phase which led to the economy overtaking South Africa as Africa's largest economy. Another surprising finding is that I also observe significant growth in terrorist murders during the 2014 Ebola crisis, implying that the terrorists are strongly motivated by the need to remain in the spotlight. However, the 2012 Nigerian flash floods that covered about $83 \%$ of the country in 2012 did not appear to have any significant effect and thus cannot be assumed to be a cause of higher terrorist fatalities in Nigeria relative to Somalia observed in the data. Also, the celebratory 2012 US Presidential visit to West Africa was widely covered in Nigeria, and although it might have tempted terrorists to commit more violence to hold Nigerians' attention, I do not find a significant correlation, which might imply some arbitary limits to the terrorist demand for public attention. A related reason why these shocks might be considered qualitatively different may be a disciplining desire among terrorists to avoid overreaching and turning off sympathizers. The term Boko Haram itself means "education is forbidden", which might imply that the murders of Boko Haram would tend to center on the national primary education examination testing period (each May/June). I do not find that Boko Haram attacks are significantly associated with the Basic Educa- 
tion Certification Examination ever year in the data, implying that perhaps its anti-education stance is merely a means of maintaining public attention. Another mechanism through which ideology may influence fatalities is through the observance of Ramadan, which may coincide with reduced fatalities if terrorists are devout, or perhaps with worsened fatalities as Ramadan has been shown to affect economic growth and well-being (Campate and Yanagizawa-Drott, 2015). Although Boko Haram and Al Shabaab both claim to have religious motivations, I do not find their fatalities to significantly vary during Ramadan. The fluctuations of murders with broader news-related factors, however, implies that attention may be a broader, more general driving force behind the operations of the terrorist group, with education and ideology being less important in practice.

I use the ACLED dataset (Armed Conflict Location and Event Data Project, 2014), which contains the universe of terrorist attacks in Africa. ACLED collects real-time data on political violence and protest in both African and Asian states, collected from various local and global media news sources in near-real-time. I focus on the codes, dates and locations of all reported political violence and protest events in Nigeria and Somalia between 2011 and 2014 for this comparative analysis. Terrorists may use relatively extremist acts to monopolize public attention. If this proposed narcissism outweighs terrorists' self-reported motivations for violence, extremists' credibility may be undermined. Since fatalities do not significantly associate with the national basic school entrance exam when the loss of public attention is accounted for, Boko Haram appears deluded in its claim at best.

The research builds on an emerging body of work focusing on the relationship between the media and the incidence of violent attacks. Policy makers may arrange for politically-unpopular measures to coincide with newsworthy events that distract the media and the public, exploiting violent affairs such as military strikes (Durente and Zhuravskaya, forthcoming). Whether or not terrorism is driven by media coverage is unclear, however. Emerging work has found a relationship between media coverage and terrorism by exploiting headline-grabbing attacks (Jetter, 2016). However, other work found that media coverage, measued by the number of column inches in the New York Times, did not actually influence the emergence of future terrorist attacks (Nelson and Scott 1992; Enders and Sandler 2012). Terrorism survivors may fear that living or working in a place that has experienced an attack would mean exposing themselves to future attacks (Manelici, 2016), implying that terrorists 
may be less interested in gaining notoriety from attacks in order to maximize the efficiency of future attacks. One way to bring clarity to the debate would be to see what occurs when terrorists lose attention through plausibly exogenous shocks. Another would be focusing on how the severity of violence reacts to such changes, not merely the incidence of attacks. Most research considers single terrorist groups individually or in unison, instead of comparing multiple terrorist groups, which may be one reason for the gap in the literature. The factors influencing relative terrorist deaths, still remains unexplored to the best of my knowledge.

Although all terrorist violence is obviously catastrophic, terrorist attacks may vary significantly in terms of their severity. There are reasons why this fact may be at least as important as the existing focus on terrorism at the level of attacks. Although some attacks may be deliberately designed to be significantly costly in terms of human lives, others may destroy property with few to no fatalities. Relative to the quantity of attacks, we have little evidence of what drives the relative severity of certain terrorist attacks relative to other extremist attacks. Given that the media in Africa is less developed relative to the rest of the world, and that African terrorism may be scarcely reported in the international media relative to attacks on Western soil, it is unclear what mental calculus African terrorists engage in when deciding how brutal their violence is going to be. Another contribution of the paper is its focus on African terrorism, which may be the next-generation of the erstwhile African warfare most often covered in recent research (e.g. Blattman, Jamison and Sheridan 2016; Ray, Debraj, and Joan Esteban 2016). Yet, there might be lessons from the Africa's violent past that resonate with contemporary African terrorism. For instance, the very violence that partitioned Africa into countries (like Nigeria and Somalia) itself occurred in the context of heightened competition for attention at the geopolitical level (Crowe, 1942; Michalopoulos and Papaioannou (2016)). This paper focuses on newsworthy events as signals of hope or hopelessness that appeal to terrorists' sense of self-importance within market-oriented settings where attention is important (Falkinger, 2008), while extending discussions on the political dimensions of inequality ( Acemoglu, Naidu, Restrepo and Robinson 2014) to settings of conflict where terrorists' attention towards events may vary. Finally, I attempt to compare terrorists' stated preferences with their revealed preferences in the data.

The findings follow through on the idea in political and behavioral science that although vio- 
lent actors tend to claim to act on behalf of a wider constituency, the perspectives of such publics are never verified (Crenshaw 1981). The findings also complement a body of work that tended to argue that violence has not only rational but also psychological elements. For example, Romano (1984) and Ross (1993) consider psychiatric factors influencing terrorist violence. Contrary to erstwhile theories that a sense of inferiority motivates individuals to commit violence, the contemporary social psychology literature notes that it is not merely the level of esteem, but the stability that influences violent acts, opening that literature to the threatened egos (Bushman and Baumeister, 1998; Lambe, Hamilton-Giachritsis, Garner, and Walker 2016). Narcissism becomes psychologically relevant when individuals have grandiose yet vulnerable self-concepts underlying the need for constant external validation (Morf and Rhodewalt, 2001). I provide empirical evidence within the context of African terrorism.

In the remaining portions of the article, I first discuss terrorism markets for attention. Afterwards, I focus on Boko Haram in Nigeria to ask: how do these terrorists respond to factors that may pull public attention away from them relative to Al Shabaab in Somalia? I finally document how several factors have affected the severity of violence and rendered Boko Haram's claimed motivations in doubt before closing the paper ${ }^{1}$.

\section{Model}

Consider a model in which a minority population of violent actors such as terrorists gain utility by being on the mind of the majority public population. The terrorist group is therefore a firm which expects more sales when it is occupies a larger share of the minds of consumers (Falkinger 2008). The more a terrorist group succeeds in bringing its "project" of hopelessness to the attention of "investors" (i.e. the public), the more likely it is to attract support for realizing and actualizing said project. In the model, I consider hopelessness to be a psychological sentiment that represents a subjective lack of well-being, or a lack of happiness casued by strictly by terrorist fatalities. According to the 2015 World Happiness Report (Helliwell, Huang and Wang, 2015), both Nigeria and

\footnotetext{
${ }^{1}$ See the Online Appendix for results that show that the findings are robust to including other armed groups and other supplementary results
} 
Somaliland reported broadly comparable levels of happiness between 2012 and 2014, with Nigeria ranking 78 and Somaliland ranking 91 globally.

\subsection{Terrorists}

Consider a set of actors called terrorists summarized as $\mathcal{A}=0, \ldots A$ who play the role of "sellers" of hopelessness. Also consider a total mass of "buyers" $B$, who are public citizens. An observed terrorist signal (i.e. a terrorist attack that results in killings) is denoted $\theta$, so that $\theta<B$, and the effective signal to induce hopelessness in the citizenry is given as:

$$
\text { Effective signal } \equiv \min \{\theta, B\}
$$

The terrorist groups acquires entries on the mind of random bereaved citizens by implementing attacks on victims.

Assumption 1: Terrorist killings with $\beta_{\min }$ murders "buys" a seller one (1) single entry in the mind of a randomly-chosen buyer in range $b$.

The "mindshare" of different bereaved citizens are interchangeable: terrorists do not get extra utility from attacking particular citizens and attack people they are not personally acquainted with. The number of entries acquired by $a \in \mathcal{A}$ is $\psi_{t}$. Multiple attacking violent groups are considered as multiproduct firms without loss of generality.

There is competition for attention among different violent actors to sell hopelessness. Acquiring $\psi_{t}$ entries requires terrorists to generate and send $\beta_{t}=\psi_{t} \beta_{\min }$ signals. The cost of producing and distributing strength $\beta$ over range $b$ is $C(\beta, b)$, whereby $C_{\beta},(\beta, b)>0, C_{\beta \beta},(\beta, b)>0$, and $C_{\beta},(\beta, b) \geq$ 0.

Assumption 2: Costs are increasing in the number of killings.

Costs are incurred since being on the public's mind is profitable and each entry brings an item to the attention of a member of the public. 
In the vein of Josef Falkinger (2008), the attention profit that can be extracted from the public is of the form

$$
\Pi=b \pi\left(\psi_{t}\right)-C\left(\beta_{\min }, b\right)
$$

whereby we assume in the standard way that $\pi\left(\psi_{t}\right)$ is earned from each member of the public addressed with strength $\psi_{t} \beta_{\min }=\beta_{t}$ and the capacity of reaching $b$ receivers so that each $a \in \mathcal{A}$ chooses $\Pi$, given $\beta_{\min }$. There are limits on the ability of the public to process violence:

Assumption 3: The public has a defined mental capacity so that processing a new marginal signal depends on the capacity left after processing other signals.

This capacity depends entirely on the effort of the public. To be perceived as an additional information source by a receiver exposed to total signal exposure $\alpha \geq \alpha_{0}$, a terrorist sender must send with strength $\beta_{\min }=q \alpha$, where $q$ is a constant. The filtering mechanism is

$$
\beta_{\min }= \begin{cases}1 & \text { if } \alpha<\alpha_{0} \\ \frac{\alpha}{\alpha_{0}} & \text { if } \alpha \geq \alpha_{0} .\end{cases}
$$

Each $a \in \mathcal{A}$ brings $y_{t}$ items to the attention of $b$ buyers drawn from total mass $B$ (and I discuss this in the next section), so that the individual choice set is

$$
W_{i}=\frac{1}{B} \int_{\mathcal{A}} B \psi_{t} d t \equiv W
$$

I assume that the choice sets $\mathcal{W}_{i}$ of different buyers may overlap but are generally not identical. Since each firm reaches all buyers $(b=B)$ all buyers are aware of the same items and the information of an attack diffuses completely across the society in the model.

The fact that each item in $\mathcal{W}_{i}$ is brought to buyer attention with strength $\beta_{\min }$ implies that total signal exposure $\alpha=W \beta_{\min }$. Substituting into equation (1) provides the following constraint 


$$
M=\alpha<\alpha_{0}
$$

and

$$
\beta_{\min }=1
$$

Meaning that only the absolute perception threshold $\beta_{\min }=1$ must be passed to be in a buyer's choice set. It's diversity, $W$, is determined by the competition of sellers for buyers.

Now, I aggregate the collective mindstate of the public and denote this mindset as $O$ where

$$
0<O \leq 1
$$

or, in a continuum of fractions from optimism (zero) to pessimism (one). The murders which succeed to be attended by the buying public compete for the buyers' budget, which has self-control elements in the model.

\subsection{The public}

The public has preferences $U(\beta)$ so that at time $t=1, \ldots, T$ :

$$
U(\beta)_{t}=u\left(\left[\int_{0}^{1} \mathcal{W}_{i} h_{g}^{\varphi} d g\right]^{\frac{1}{\varphi}}\right)_{0}+\gamma \int_{t=1}^{T} \delta^{t} u\left(\left[\int_{\mathcal{W}_{i}} h_{g}^{\varphi} d g\right]^{\frac{1}{\varphi}}\right)_{t}
$$

where $\gamma \leq 1$ is the short-term discount factor and $\delta$ is the long-term discount factor. An unsophisticated public is unaware of their time-inconsistent preferences and thus, does not move from optimism towards pessimism. The public puts a larger weight on pessimism today than in the future, and may become optimistic and find reasons to "look on the bright side" (when an attack rationally calls for pessimism) due to this self-control problem.

Proposition 1: For an equilibrium, terrorists must maximize their attention profits. 
Terrorists are interested in killing as many people as possible in the model which I interpret as maximizing attention profits. The public values future reward peace less than peace in the present when deciding how much hopelessness the present warrants. These outcomes are a natural consequence of the public having time-inconsistent preferences and is consistent with the literature arguing that certain areas of the brain associated with emotional rewards are activated only by instant gratification, and are not activated by thoughts of future gratification.

Fact:Terrorists gain $q^{*}<q^{\prime}$ where $q^{\prime}$ would occur under a regime where the public is time-consistent.

More terrorist violence occurs in the time-inconsistent environment than would occur in a time-

consistent setting, or where $U=\left[\int_{0}^{1} \mathcal{W}_{i} h_{g}^{\varphi} d g\right]^{\frac{1}{\varphi}}$. Due to the public's self-control problem, the terrorists must present the public with a "commitment device" in the present scenario (where the public is time-inconsistent), which would not be needed if the public were rational. In Section 4 I discuss how the terrorists respond to competing events in terms of fatalities. Every action of the public from pessimism towards optimism (as a result of the public self-control problem) is interpreted as a signal by the terrorists, which responds by committing violence. The goal of the violence is to "commit" the public to hopelessness, in the vein of a commitment device.

I now add a layer to the discussion by introducing unequal attention before allowing terrorists to respond to external events that are possibly noisy signals to terrorists that take actions that affect both terrorists and the public. The terrorists respond to occasions considered to be stronger attention threats by providing more killings relative to news considered to be weaker attention threats within the context of a public with limited self-control.

\subsubsection{Identification of Events that Lead to Unequal Attention}

To motivate inequality in optimism and attention received by terrorists from elements of the public, I let the $B$ agents differ exclusively through their attention-spans $\omega_{b}$, so that the distribution of attention averages $\bar{\omega}$. The distribution is represented by the function $v(\omega)$. I assume an external 
treatment event $\tau$ that distributes optimism to all agents in the society. Every event has benefits (e.g. informational in scope) and costs (efforts exerted). I contextualize inequality in a simple benefit-cost environment.

The budget constraint that influences the policy,

$$
M \leq \underbrace{\tau \bar{\omega}_{b}}_{\text {benefits }}-\underbrace{C(\tau) \bar{\omega}}_{\text {costs }}
$$

consists of the benefits $\tau \bar{\omega}_{i}$ and costs $C(\tau) \bar{\omega}$, whereby $C(\tau)$ is differentiable, convex and nondecreasing. Each agent's utility after the policy is received is in the form

$$
\hat{\omega}_{i}=(1-\tau) \omega+\tau \bar{\omega}_{i}-C(\tau) \bar{\omega}
$$

where

$$
u\left(\hat{\omega}_{i}\right)_{t}=u\left(\hat{\omega}_{i}\right)_{0}+\gamma \sum_{t=1}^{T} \delta^{t} u\left(\hat{\omega}_{i}\right)_{t}
$$

Suppose that all agents above $\omega_{q}$, the $q$ th percentile of the attention distribution are exposed to the policy and optimistic and the rest of the distribution are unoptimistic. Consider an unexpected event, which takes the form of $\omega_{q}$ which is decreasing to $\omega_{q}^{\prime}<\omega_{q}$, so that more people have opti-

mism. Let the equilibrium global optimism rate under these regimes be $\tau_{q}$ and $\tau_{q}^{\prime}$ so that the post policy distributions are $\pi_{q}(\omega)$ and $\pi_{q}^{\prime}(\omega)$. Suppose that startng from only those above $\omega_{q}$ becoming optimistic, there is a further gaining of optimism so that $\omega_{q}^{\prime}<\omega_{q}$. This leads to a more equal distribution of optimism. The median of the distribution truncated at $\omega_{q}^{\prime}$ is lower than the median of the distribution truncated at $\omega_{q}>\omega_{q}^{\prime}$. At time $t=1, \ldots, T$, more people have optimism than at time $t=0$, so that $\omega_{q}^{\prime \prime}<\omega_{q}^{\prime}<\omega_{q}$. The post policy distributions become $\pi_{q}^{\prime}(\omega)$ and $\pi_{q}^{\prime \prime}(\omega)$.

\subsubsection{Signaling optimism and terrorist responses}

In the model, the public desires to provide signals to terrorists in a effort reduce to violence but the actualized signal ends up increasing violence due to the public's self-control problem. Terrorists 
follow Bayes' Rule in their actions. The inequality is explained by the different signals sent, based on how a particular event resonates with the public.

Proposition 2:An equilibrium is an action rule for terrorists $A$, labelled $\psi(n)$, and for the public $B$, a probability distribution $\mu$ on the Borel-measurable subsets of

$$
[0,1] \times[N]
$$

so that

$$
\mu(W \times[N])=\int_{\mathcal{W}_{i}} f
$$

for all measurable sets $W$.

Specifically, an equilibrium consists of a family of signaling rules for $B, s(n \mid m)$, and an action rule for $A$, denoted $\psi(n)$ such that:

1. For each $m \in[0,1], \int_{N} s(n \mid m) d n=1$, where the Borel set $N$ is the set of feasible optimism signals, and if $n^{*}$ is in the support of $s(\cdot \mid m)$, then $n^{*}$ solves $\max _{n \in N} U^{S}(\psi(n), m, b)$. This first condition observes that $B$ 's signaling rule yields an expected utility action for each self-control "type", taking the action of terrorists $A$ as given.

2. For each $n, \psi(n)$ solves $\max _{\psi} \int_{0}^{1} U^{R}(\psi, m) p(m \mid n) d m$,

where

$$
p(m \mid n) \equiv \frac{s(m \mid n) f(m)}{\int_{0}^{1} s(n \mid t) f(t) d t}
$$

This second condition implies that terrorists $A$ respond optimally to each possible signal, using Bayes' Rule to update their priors, whereby $\int_{0}^{1} U^{R}(\psi, m) p(m \mid n) d m$ is strictly concave in $\psi$, which disallows the use of mixed strategies in equilibrium in such settings, (see Vincent Crawford and Joel Sobel, (1982)). 
This simple model shows that terrorist violence can arise when the public is living in a broader environment of optimism. It also implies that attacks that compete for the attention of the budget of the public must be severe to gain this attention. This approach is instructive and suitable for terrorist violence in general, as hinted by the reliance of international terrorist groups on social media and other avenues of holding and maintaining global public attention. Certainly, the socioeconomic environments of Nigeria and Somalia are more complex than the presented model. For example, other military units such as rebel groups and protest movements co-exist with terrorist groups in both Nigeria and Somalia during the period analyzed by the study, and the governments of these countries implement attacks of their own to fight the terrorists and end up causing citizen casualties as well. However, I show in the results section that fatalities caused by terrorist groups are sustained even when the data is extended to include fatalities caused by other actors. The facts suggest that terrorist attacks are important and a significant driver of fatalities in both Nigeria and Somalia. The model also abstracts from other policies implemented in Northern Nigeria and Somalia in the timeframe by non-governmental organizations. I make this simplification because I show that optimistic news that might make such areas attractive to policy makers leads to worse violence, which would discourage such charities in the short term. I assume that the self-control problem of the public induces a self-control problem in terrorists as far as consistency to their ideologies are concerned.

Thus, the simplified model limited to terrorists and the public working through the attention of citizens and self-control problems is helpful for the empirical investigation. In Section 4, I show that the effect of related factors on terrorism are confirmatory, in line with recent developments on terrorist phenomena. I provide three related hypotheses of the effects of events, which I call "attention shocks":

Hypothesis 1: Terrorists respond to attention shocks by conducting more terrorist attacks in a bid to keep the attention of the public.

Hypothesis 2: The fatalities of terrorist violence is increasing in the perceived relative ability of attention shocks to keep the attention of the public away from terrorism and towards optimism.

Hypothesis 3: The fatalities of terrorist violence due to attention shocks exceeds fatalities attributable to ideology.

I describe the terrorist groups in the next section before introducing the data, approach and 
results.

\section{Boko Haram and Al Shabaab}

The multidisciplinary literature presents an emerging number of comprehensive case profiles into Boko Haram and Al Shabaab, only briefly summarized here. In Nigeria, the stratospheric rise of Boko Haram since 2009 and the renewed violence after 2010 occurred in the wake of previous small-scale attempts to impose religious ideologies on Northern Nigeria. The success of Boko Haram has been accelerated by a growing ability to challenge the legitimacy of the Nigerian state, whose seeming ineptitude was becoming increasingly apparent with regular outbreaks of violence across Nigeria (Adesoji, 2010; Onuoha 2010). Boko Haram's attacks stabilized after the group went underground after widespread killings by government soldiers but re-emerged with multiple attacks since 2011. In Nigeria, a sway of optimism has been critical for Nigerians to maintain economic development policies and a growing national democracy in spite of the violence.

In Somalia, a deterioration of political order since 2006 occurred in the wake of successful military strikes by the Ethiopian government. The context of the rise of Al Shabaab was to fill a governance vacuum in large swaths of Somalia (Gartenstein-Ross, 2009; Verhoeven, 2009; Mwangi, 2010; Vidino, Pantucci and Kohlmann, 2010). Al Shabaab ultimately benefitted from extremists exploiting safe havens along the Pakistan-Afghanistan border who were entering East Africa. Although Al-Shabaab gained support by promising people security in a failed state, its credibility suffered significantly when it rejected Western food aid to combat a 2011 drought and famine. With Mogadishu and other towns now under government control, many Somalis returned from exile after the famine, bringing their money and skills with them. Basic services such as street lighting, dry cleaning and rubbish collection have resumed in the capital.

\subsection{Events and Attention Shocks}

Although the political contexts of Nigeria and Somalia are distinct, they have been broadly comparable during the period under study. Nigeria's elections are held every five years since the return to 
democracy in 1999, and the 2011 set of elections were held in April. Observers considered these elections as the most smoothly run elections thus far, with the United States State Department and other actors considering the election a significant improvement. Crowd-sourcing and social media may have helped the process (Lazarus and Saraf, 2015). Unfortunately, Somalia has not had general elections since the 1980s, although the country experienced some humanitarian assistance in 2011 to slightly improve conditions of hunger and famine (Global Peace Operations Review, 2012).

Given the relatively comparable state of affairs in this context, I look at terrorist fatalities to assess how the terrorists react to scarce attention in 2012 through 2014, isolating attention shocks that disproportionately affected Nigeria relative to Somalia:In Table 1, I summarize relevant sociopolitical events that may have affected the severity of terrorist attacks by distracting the public from terrorism as well as other relevant information.

[Insert Table 1]

Flash Flooding. The 2012 Nigeria floods were the worst the country had experienced in four decades. The flash floods began in early July 2012, displacing more than 2 million people and affecting 30 of Nigeria's 36 states. Somalia experienced a significantly smaller flood in September 2012, which was limited to one city, Beledweyne (affecting $1 \%$ of the population). The severity of the flash flooding may have either suppressed Boko Haram terrorists relative to Al Shabaab terrorists. On the other hand, Boko Haram may have worsened their attacks to maintain public attention.

The Visit of US President to Africa. President Barack Obama and the First Lady Michelle Obama traveled to Senegal, South Africa, and Tanzania to meet with leaders and affirm the commitment of the United States to African economic development. This visit was hotly anticipated in Nigeria (although the US President did not actually visit Nigeria) in part because Nigeria was not visited during the President's original diplomatic visit to Africa in 2009, in spite of the size of its economic and political importance to the African continent. Unfortunately, Somalia was not on the policy radar at the time. The attention paid to the United States President may have demotivated Boko Haram terrorists relative to Al Shabaab terrorists. Alternatively, the visit may have encouraged Boko Haram to carry out more deadly attacks to keep public attention on the terrorist group. 
The first rebasing of the Nigerian economy in two decades. Following a revision of Nigeria's GDP (Gross Domestic Product) data in 2013, Nigeria's National Bureau of Statistics recalculated the value of GDP based on production patterns in 2010, increasing the number of industries it measured from 33 to 46 and giving greater weighting to newer sectors such as the mobile phone sector. Nigeria's economic size grew by about $75 \%$ to an estimated 80 trillion naira (about $\$ 488$ billion). As Nigeria overtook South Africa to become the largest economy in Africa and the twenty-fourth largest globally, Somalia's economic standing has remained relatively stable as one of the poorest economies in the world. Although the rebasing did not mean that Nigerians became $75 \%$ wealthier, it may have had implications for terrorism given the signal sent to international investors. The optimism encouraged by the rebasing may have discouraged Boko Haram terrorists relative to $\mathrm{Al}$ Shabaab terrorists in terms of how severe their attacks became following the perceived economic restructuring. On the other hand, the rebasing may have encouraged worse terrorist attacks by encouraging a sense of optimism about Nigeria's economic future.

The Bring Back Our Girls Campaign. In April 2014, Boko Haram terrorists kidnapped 276 school girls, generally between 16 and 18 years old. A strong outcry in Nigeria evolved into a global viral campaign called "Bring Back Our Girls" aimed at raising awareness and exerting pressure on the Nigerian government to ensure the safe return of the girls to their families. The cause gained the support of various international media personalities and celebrities (such as First Lady Michelle Obama). This unusual campaign may have demotivated Boko Haram terrorists relative to Al Shabaab in Somalia, where no such campaign occurred. Alternatively, Boko Haram may have felt emboldened by the global attention and worsened fatalities in response. Given the potentially particularly high endogeneity of this political campaign which was in direct response to Boko Haram, I do not hypothesize the campaign having more than a correlational effect. I therefore do not emphasize the campaign, although I still find it important to control for this activism in the regressions for robustness.

The Ebola Crisis. The Ebola virus emerged in Lagos, the capital of Nigeria on 20th July 2014, leading to seven deaths and nineteen infections before the outbreak ended on 20th October. The World Health Organization and other actors noted the efficient coordination of the Nigerian government officials which ensure that the crisis was short-lived, while drawing attention to the 
need for robust health infrastructure in the country. The Ebola crisis may have discouraged Boko Haram from carrying out fatalities, perhaps for fear of becoming infected with the Ebola illness. On the other hand, Boko Haram may have felt threatened by losing the spotlight, even to a crisis.

\subsection{ACLED Data Source}

The ACLED project codes reported information on the exact location, date, and other characteristics of politically violent events in conflict regions (see Clionadh Raleigh and Caitriona Dowd (2016) which contains a thorough description of the dataset). Data contain specific information on the date of the violent incidence; the location or area or administrative unit that hosted the violence; the type of violence that occurred as well as how many fatalities were caused by the violence. The data is more fully described in the Online Appendix. I focus on terrorist attacks conducted by terrorist and other violent actors. Figure 1 documents terrorist attacks in Nigeria versus Somalia.

Figure 1: Terrorist Attacks by Boko Haram and Al Shabaab, 2011-2014

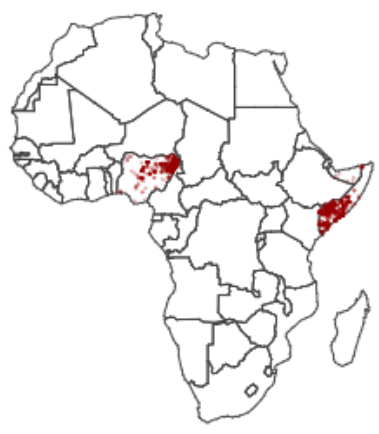


The average daily fatalities are summarized in Figure 2. The diagram shows that the growth on daily average fatalities attributable to Boko Haram relative to Al Shabaab. The largest spikes appear to coincide with the Ebola crises.

Figure 2: Daily Averages of Fatalities from Terrorist Attacks by Boko Haram and Al Shabaab,

2011-2014

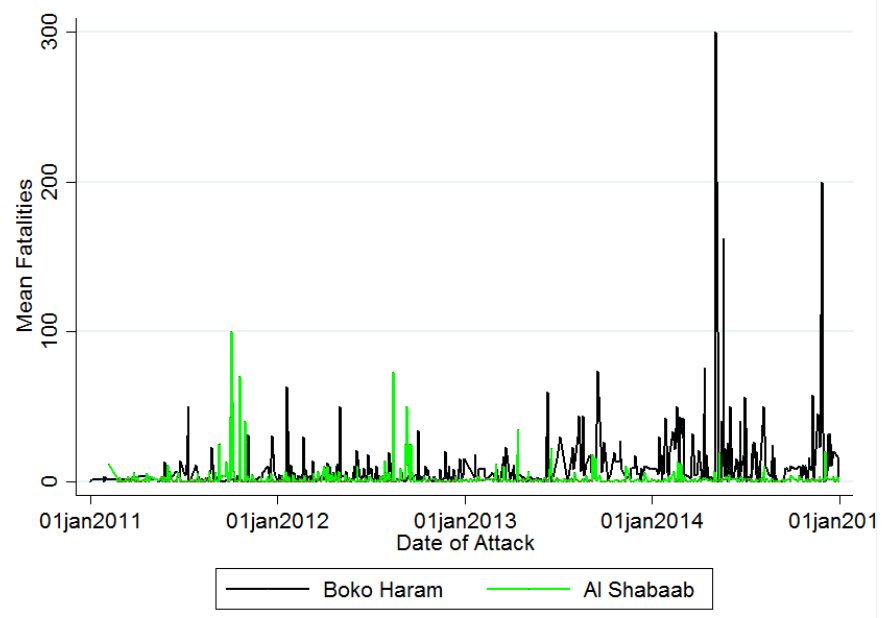

\section{Reduced Form Evidence of Attention Shocks and High Ter- rorist Fatalities}

In this section I provide reduced-form evidence of the effects of the attention shocks on the likelihood of killing more people than terrorists kill on average. Being exposed to attention shocks is generally followed by committing terrorist strikes that kill more people than average. When unexposed to the loss of attention, Boko Haram terrorists generally kill fewer people in their terrorist attacks than Al Shabaab. When attention is lost to other events, Boko Haram conducts attacks that kill significantly more people than Al Shabaab does. I focus on the proportion of attacks that resulted in more than 4.4 deaths, which is the average number of deaths from terrorist attacks. The treatment group in Figure 3 refers to the 2012 flash flooding period. The proportion of high Boko Haram fatalities is about $10 \%$ higher than that of Al Shabaab. 
Figure 3: Flash Flooding and High Terrorist Fatalities

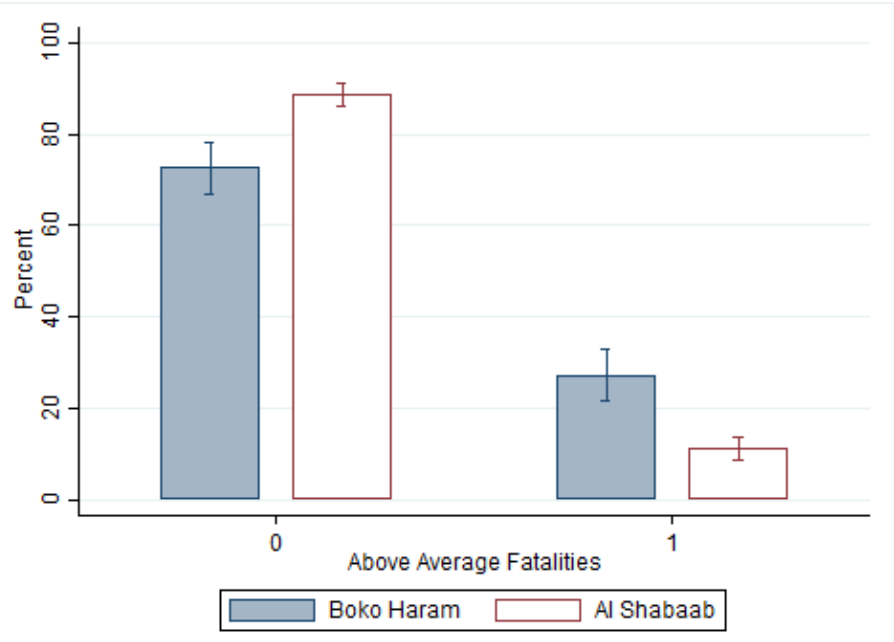

Figure 4 displays the proportion of attacks that resulted in more than four deaths, while focusing on the effect of the United States President's visit to Africa. The proportion of high Boko Haram fatalities is about $20 \%$ higher than that of Al Shabaab during the period of the visit. Boko Haram attacks that resulted in high fatalities changes negatively by about $20 \%$ whereas Al Shabaab attacks that resulted in high fatalities changes negatively by more than $70 \%$.

Figure 4: US President Africa Visit and High Terrorist Fatalities

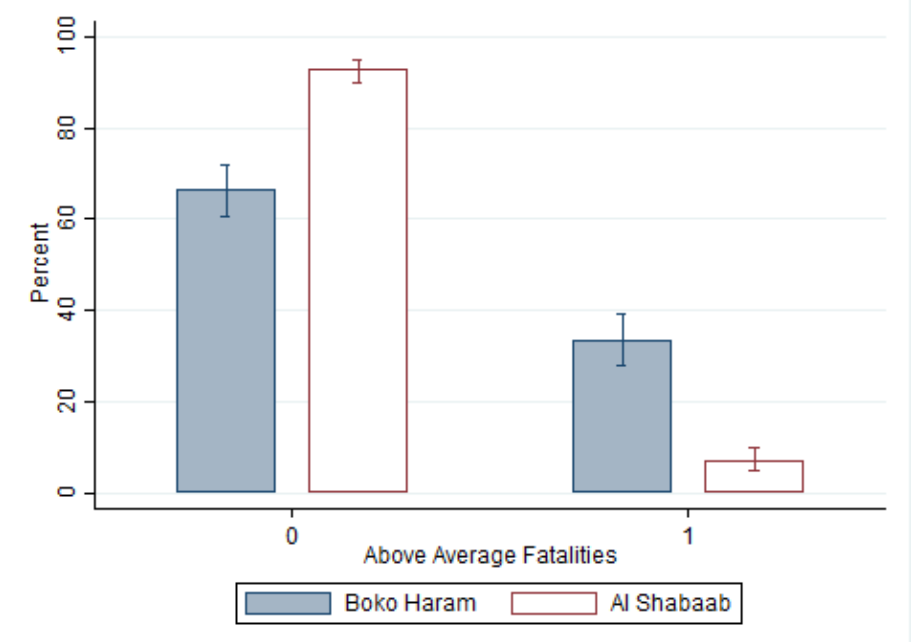


Figure 5 displays the proportion of attacks that resulted in more than four deaths, while focusing on the effect of the GDP rebasing. The gap between the proportion of high Boko Haram fatalities and that of Al Shabaab is larger than the gap attributable to the flash flooding or the US Presidential visit. Boko Haram attacks that resulted in high fatalities changes positively by about $60 \%$ whereas Al Shabaab attacks that resulted in high fatalities changes negatively by more than $70 \%$.

Figure 5: Economic Rebasing and High Terrorist Fatalities

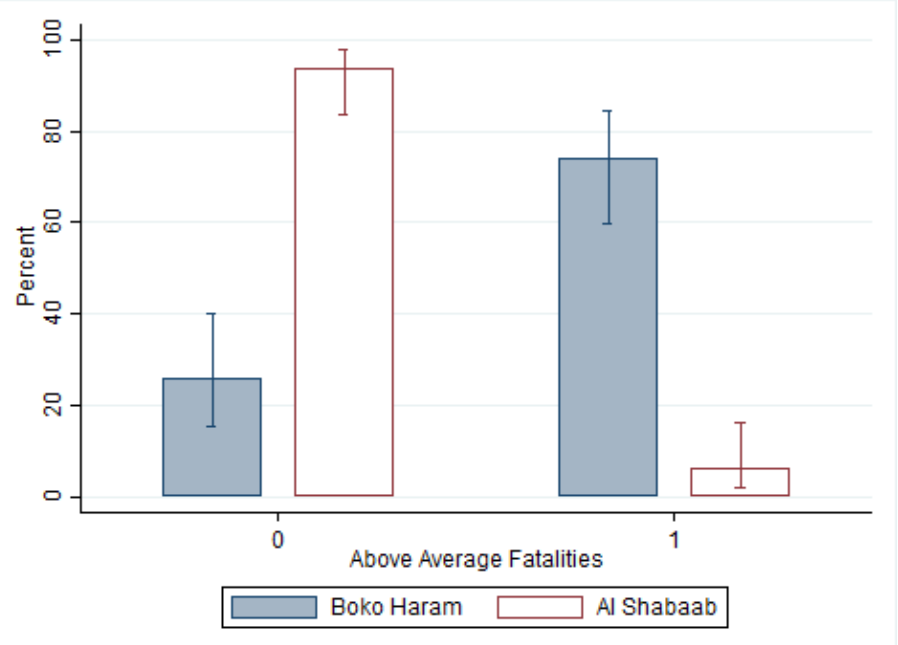

Figure 6 displays the proportion of attacks that resulted in more than four deaths, while focusing on the effect of the Ebola crisis. The gap between the proportion of high Boko Haram fatalities and that of $\mathrm{Al} \mathrm{Shabaab}$ is comparable to the gap during the economic rebasing. I find a growth in Boko Haram terrorist attacks that lead to high levels of fatalities, and a decline in such terrorist attacks committed by Al Shabaab

Figure 6: Ebola Crisis and High Terrorist Fatalities 


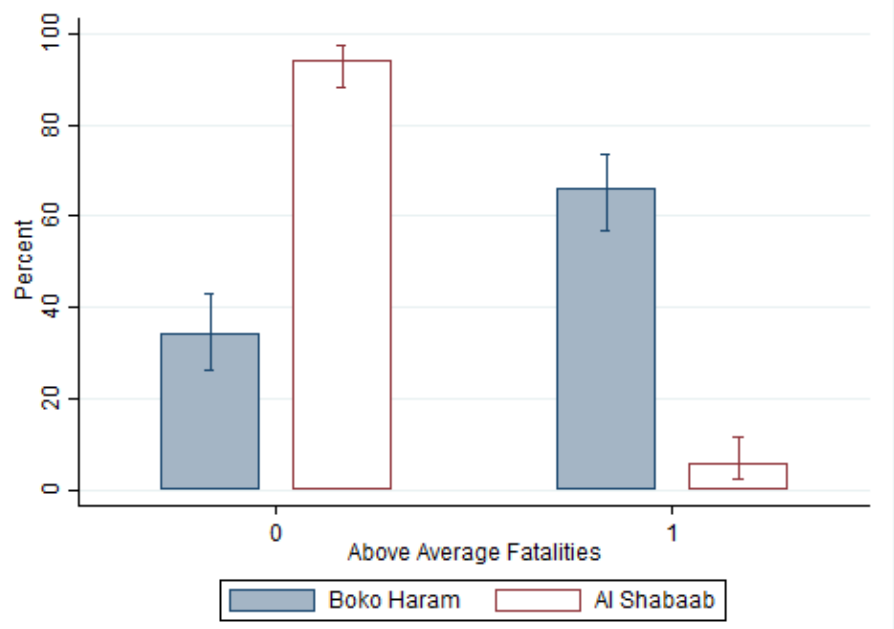

\subsection{Summary Statistics and Regressions}

In this section I provide summary statistics and regression results that are more comprehensive than the descriptive results provided above to assess their robustness. Table 2 provides summary statistics on Boko Haram and Al Shabaab. The terrorist fatalities average about 4.4 casualties per reported day between 2011 to 2014 in the data, with 36\% of the attacks implemented by Boko Haram and the remaining 64\% committed by Al Shabaab. The types of conflicts (based on outcomes) were classified as battles in which the (Nigerian or Somali) government regained territory (only $0.5 \%$ ), battles that did not result in a change of territory (i.e. Boko Haram or Al Shabaab retained control of the area (34\%), battles in which non-stake actors overtook the territory $(0.3 \%)$. Battles in which headquarters of a base were established, non-violent activity by the conflict actor in question; nonviolent transfer of territory, remote violence, riots or protests and violence against civilians, which the last conflict type accounting for $41 \%$ of the reported conflicts.

[Insert Table 2] 


\subsection{Main Results}

In this section, I look at how Boko Haram's violence has changed as a result of these shocks to the terrorist group's public attention, relative to Al Shabaab. I provide OLS regressions that control for the type of conflict, the various attention shocks, the Bring Back Our Girls campaign in Nigeria, and year dummy variables. The comparison group in all regressions is Al Shabaab. I also note that the terrorist attacks had variation in the quality of their reporting in the data. To illustrate, some attacks had their specific date reported, whereas other attacks had their week reported. I control for dummy variables that capture this precision. Clustering of robust standard errors occurs at the level of the administrative area that experienced the attack. The dependent variable is the number of fatalities that occurred due to each terrorist attack.

\subsubsection{OLS Regression Results}

In Table 3 I shows the OLS regressions, focusing on Boko Haram and Al Shabaab. Under the more robust specification, the 2012 flash flooding does not appear to have a significant correlation and neither does the US presidential visit. On the other hand, the rebasing of Nigeria's economy appears to have been interpreted as a threat by Boko Haram as was the Ebola crisis in 2014, which shows the strongest relationship with Boko Haram fatalities. Rebasing the Nigerian economy and the Ebola crisis seem to best contextualize the killings of Boko Haram relative to Al Shabaab. Thus, the Boko Haram violence is best understood within the contexts of the rebasing policy as well as the Ebola crisis, both of which redirected attention away from terrorism. In the Online Appendix, the same regressions are run with the data extended to other armed groups in Nigeria and Somalia with the results being consistent with the results below.

[Insert Table 3] 


\section{Is Boko Haram Anti-Education or Attention-Seeking?}

The findings thus far imply that the motivation of terrorists may be assessed within the context of behavioral phenomena that center on attention. I observe how Boko Haram attacks vary during the Basic Education Certificate Examination (BECE) exams, which occur in May/June every year. The proportion of Boko Haram attacks that occur during the BECE are only about $1 \%$. In Table 4, I present a regression that checks for the effect of the BECE is on an annual basis when the attention shocks are controlled for in the same regression. Interestingly, the BECE effect is only significant for the year 2011 (in which it declines, in line with the broader trend). The significant increase in casualties particularly during the Ebola crisis, and the rebasing of the currency are robust to these inclusions as well. From Table 5, it appears that the effect of the BECE and the anti-education stance is not actually a main driver in practice. Instead, it appears that attention shocks are the main factor influencing fatalities by terrorists. I thus conclude that Boko Haram's motivation has more to do with the terrorist group's attention-seeking character instead of some misguided protest of formal education.

[Insert Table 4]

\section{Are Boko Haram and Al Shabaab Religious?}

I estimate the importance which Boko Haram and Al Shabaab empirically place on religion by investigating how fatalities vary during the Ramadan period throughout the study. Table 5 analyzes the effect of Boko Haram and Al Shabaab on fatalities when the terrorist groups are interacted with the period of the Ramadan, which occurred in July and August in 2011, 2012 and 2013, and from June 28 through July in 2014. The regressions in this section include all other armed groups in Nigeria and Somalia which serve as comparison groups. About $18 \%$ of the attacks occurred during Ramadan. I relegate the other summary statistics to the Appendix, which also shows that all regressions in the paper are robust to acknowledging such conflict groups. The terrorist groups' fatalities do not significantly vary during the Ramadan, implying that they are not as devout as such extremist 
groups may desire recruits to believe. The other armed conflict actors and rebel groups in Nigeria and Somalia, which do not make anti-education or religious claims to the extent that Boko Haram and Al Shabaab do, seem to be driving the declinee in fatalities during the Ramadan periods. On the other hand, the attention-based Boko Haram variables are robust to the inclusion of the Ramadan variables. Again, the rebasing of the Nigerian currency and the Ebola crisis show statistically significant associations with Boko Haram casualties. The rebasing of the Nigerian currency and the Ebola crisis show statistically significant associations with Boko Haram casualties. I also control for the BECE period which is not statistically significant. This is further support for the argument that Boko Haram is motivated more by the desire for attention than an anti-education or religrious ideology as self-reported. The other educational and religion-related factors appear to play no significant role in influencing the decision of terrorists to vary how many fatalities they commit during extremist attacks.

[Insert Table 5]

\section{Conclusion}

Until now, the main attribution of Boko Haram violence has been a notorious anti-education and ideological stance, which may have yielded some impression that a credible population in Nigeria does not find utility in human capital investments and improvements. This paper instead suggests that the root of much terrorism lies in attention and the desire to keep citizens focused on terrorists. My findings show the growth of terrorist casualties in Nigeria and that two phenomena are helpful in understanding this phenomenon: the rebasing of Nigeria's economy which brought much international positive attention to the country as well as the Ebola crisis, which, had negative implications but also brought assistance to the nation as well. What these occurrances-the rebasing and the health crisis have in common then, is that they removed public attention away from terrorism. The relative severity of attack responses to attention shocks in part, implies that the attention of the public to terrorists is diverted to unequal degrees by different attention shocks. Broadly, the findings imply 
that some effect distribution exists in this context, with the rebasing of the Nigerian economy representing the most salient positive attention shock and the Ebola crisis affecting the most important negative attention shock. Interestingly, whether the shock is "good" or "bad" seems to matter little for terrorism.

It might therefore be inappropriate and inaccurate to interpret Boko Haram wholly as an antiWestern, anti-education terrorist initiative. It is true that in a general sense correlations of terrorist fatalities grow during the regional primary education examination, but these correlations do not stand closer scrutiny and are absorbed when one considers the factors that drive public attention. To conclude, the next generation of African conflict appears to be influenced by factors that are more behavioral and information-oriented than entirely rational in character. At the same time, terrorists may also face distractions in the veins that other humans do (Banerjee and Mullainathan, 2008) and attention may be strived for in market competition environments (Bordalo, Gennaioli and Shleifer, 2015). The impact of competition on information revelation may be ambiguous when the terrorists choose what information to communicate by varying their killings, if this is done in a rational way (Gentzkow and Kamenica 2016). From the findings, it is quite plausible that the public is navigating the long-awaited political-economic rise of the continent and filtering its experience of violence through such progress, motivating such violent actors to compete for attention. Whether such competition ultimately compromises the long-awaited gains in Africa is a question that deserves further research. 
Table 1: Variable and Attention Shock Event Descriptions

\begin{tabular}{|c|c|}
\hline Variables & Description \\
\hline \multicolumn{2}{|l|}{ Dependent Variable } \\
\hline Fatalities & $\begin{array}{l}\text { Number of conflict deaths. ACLED only } \\
\text { codes estimated casualties when reported by } \\
\text { source materials. }\end{array}$ \\
\hline \multicolumn{2}{|l|}{ Independent Variables } \\
\hline Boko Haram dummy & Fatalities were instigated by Boko Haram \\
\hline Al Shabaab dummy & Fatalities were instigated by $\mathrm{Al}$ Shabaab \\
\hline \multicolumn{2}{|l|}{ Event variables } \\
\hline Flash floods & $\begin{array}{l}2012 \text { Flash flooding in Nigeria which covered } \\
83 \% \text { of the country and response. (Dates: July } \\
2,2012 \text { until June } 26,2013 \text { ). }\end{array}$ \\
\hline United States Presidential Visit to Africa & $\begin{array}{l}\text { Visit of President Barack Obama to West } \\
\text { Africa, widely covered in the Nigeria media. } \\
\text { (Dates: June } 27,2013 \text { until July 2, 2013). }\end{array}$ \\
\hline Rebase Economy & $\begin{array}{l}\text { The Gross Domestic Product of Nigeria is } \\
\text { rebased to become the largest in Africa, } \\
\text { overtaking South Africa. (Dates: April 7, } \\
2014 \text { until April 13, 2014) }\end{array}$ \\
\hline Bring back our girls & $\begin{array}{l}\text { Global media Bring back our girls campaign } \\
\text { after the kidnapping of about } 200 \text { Nigerian } \\
\text { girls by Boko Haram, supported by First Lady } \\
\text { Michelle Obama, members of the Nigeria } \\
\text { diaspora and other public figures (Dates: } \\
\text { April 14, } 2014 \text { until July 19, 2014). }\end{array}$ \\
\hline Ebola crisis & $\begin{array}{l}\text { Ebola health crisis in Nigeria after infection is } \\
\text { observed. Nigeria is declared Ebola-free on } \\
\text { October 20, 2014. (Dates: July 20, 2014- } \\
\text { October 20, 2014). }\end{array}$ \\
\hline $\begin{array}{l}\text { Precision of reported } \\
\text { military attack in media }\end{array}$ & $\begin{array}{l}\text { Temporal precision showing how certain } \\
\text { ACLED is about the media attack. }\end{array}$ \\
\hline $\begin{array}{l}\text { Media source included date (Time precision } \\
\text { "1") }\end{array}$ & $\begin{array}{l}\text { The sources collected by ACLED included } \\
\text { the date while documenting the conflict event. } \\
\text { This is the highest form of precision. }\end{array}$ \\
\hline $\begin{array}{l}\text { Media source included week (Time precision } \\
\text { " } 2 " \text { ") }\end{array}$ & $\begin{array}{l}\text { The sources collected by ACLED included } \\
\text { the week. This is the second-highest form of } \\
\text { precision. }\end{array}$ \\
\hline $\begin{array}{l}\text { Media source only note that an activity } \\
\text { occurred within a particular month (Time } \\
\text { precision "3") }\end{array}$ & $\begin{array}{l}\text { If sources note only that an activity took place } \\
\text { within a particular month, without reference } \\
\text { to the particular date, the month mid-point is }\end{array}$ \\
\hline
\end{tabular}




\begin{tabular}{|c|c|}
\hline & $\begin{array}{l}\text { chosen unless the beginning or end of month } \\
\text { is noted (in which case, the first and last date } \\
\text { are used, respectively) and ' } 3 \text { ' as the precision } \\
\text { level. }\end{array}$ \\
\hline \multicolumn{2}{|l|}{$\begin{array}{l}\text { Attack type dummies (Definitions of the battle } \\
\text { types are all from }(l) \text { ) }\end{array}$} \\
\hline Battle: Govt regains territory & $\begin{array}{l}\text { A battle in which the government regains } \\
\text { control of a location. This event type is used } \\
\text { solely for government reacquisition of } \\
\text { control. A small number of events of this type } \\
\text { include militias operating on behalf of the } \\
\text { government to regain territory outside of } \\
\text { areas of a government's direct control (for } \\
\text { example, proxy militias in Somalia which } \\
\text { hold territory independently but are allied } \\
\text { with the Federal Government). }\end{array}$ \\
\hline Battle: No change of territory & $\begin{array}{l}\text { A battle whereby control of the contested } \\
\text { location does not change. This is the correct } \\
\text { event type if the government controls an area, } \\
\text { fights with rebels and wins; if rebels control a } \\
\text { location and maintain control after fighting } \\
\text { with government forces; or if two militia } \\
\text { groups are fighting. }\end{array}$ \\
\hline Battle: Non-state actor overtakes territory & $\begin{array}{l}\text { A battle whereby non-state actors win control } \\
\text { of a location. If, after fighting with another } \\
\text { force, a non- state group acquires control, or } \\
\text { if two non-state groups fight and the group } \\
\text { that did not begin with control acquires it. }\end{array}$ \\
\hline $\begin{array}{l}\text { Headquarters or base } \\
\text { established }\end{array}$ & $\begin{array}{l}\text { A non-state group establishes a base or } \\
\text { headquarters. This event is non-violent, and } \\
\text { coded when a permanent or semi-permanent } \\
\text { base is established. There are few if any cases } \\
\text { where opposition groups other than rebels } \\
\text { acquire territory. }\end{array}$ \\
\hline $\begin{array}{l}\text { Non-violent activity by } \\
\text { conflict actor }\end{array}$ & $\begin{array}{l}\text { These refer to activity in which people are not } \\
\text { physically harmed (e.g. looting or burning, } \\
\text { destruction of sacred spaces, and forced } \\
\text { displacement. }\end{array}$ \\
\hline $\begin{array}{l}\text { Non-violent transfer of } \\
\text { territory }\end{array}$ & $\begin{array}{l}\text { This event describes situations in which } \\
\text { rebels or governments acquire control of a } \\
\text { location without engaging in a violent act. }\end{array}$ \\
\hline Remote violence & $\begin{array}{l}\text { Remote violence refers to events in which the } \\
\text { tool for engaging in conflict did not require } \\
\text { the physical presence of the perpetrator. } \\
\text { Remote violence notes that the main }\end{array}$ \\
\hline
\end{tabular}




\begin{tabular}{|l|l|}
\hline \multirow{V}{*}{ Riots/protests } & $\begin{array}{l}\text { characteristic of an event is that a spatially } \\
\text { removed group determines the time, place and } \\
\text { victims of the attack. These include } \\
\text { bombings, IED attacks, mortar and missile } \\
\text { attacks, etc. Remote violence can be waged } \\
\text { on both armed agents (e.g. an active rebel } \\
\text { group; a military garrison) and civilians (e.g. } \\
\text { a roadside bombing). }\end{array}$ \\
\hline $\begin{array}{l}\text { A protest describes a non-violent, group } \\
\text { public demonstration, often against a } \\
\text { government institution. Rioting is a violent } \\
\text { form of demonstration. These can be coded as } \\
\text { one-sided events. All rioters and protesters are } \\
\text { noted by generic terms (e.g. Protester } \\
\text { (Country)), but if representing a group, the } \\
\text { name of that group is recorded in the 'ally' } \\
\text { column. }\end{array}$ \\
\hline $\begin{array}{l}\text { Violence against civilians occurs when any } \\
\text { armed/violent group attacks civilians. By } \\
\text { definition, civilians are unarmed and not } \\
\text { engaged in political violence, Rebels, } \\
\text { governments, militias, rioters can all commit } \\
\text { violence against civilians. }\end{array}$ \\
\hline
\end{tabular}


Table 2: Terrorism by Boko Haram and Al Shabaab

\begin{tabular}{|c|c|c|c|c|c|}
\hline \multicolumn{6}{|l|}{ Variables } \\
\hline Dep. Var & $\mathrm{N}$ & mean & sd & $\min$ & $\max$ \\
\hline Fatalities & 2167 & 4.376096 & 13.5918 & 0 & 300 \\
\hline \multicolumn{6}{|l|}{ Ind. Var. } \\
\hline BH: Boko Haram & 2167 & .361329 & .4804965 & 0 & 1 \\
\hline AS: Al Shabaab & 2167 & .638671 & .4804965 & 0 & 1 \\
\hline \multicolumn{6}{|c|}{ Post-2011 Election variables } \\
\hline Flash floods & 2167 & .1158283 & .3200928 & 0 & 1 \\
\hline US Pres. Visit & 2167 & .1222889 & .3276948 & 0 & 1 \\
\hline Rebase Economy & 2167 & .0230734 & .1501712 & 0 & 1 \\
\hline Bring back our girls & 2167 & .0027688 & .0525587 & 0 & 1 \\
\hline Ebola crisis & 2167 & .0581449 & .2340713 & 0 & 1 \\
\hline \multicolumn{6}{|l|}{$\begin{array}{l}\text { Post-2011 Election variables } \\
\text { interacted with } \mathrm{BH}\end{array}$} \\
\hline $\mathrm{BH} \times$ Flash floods & 2167 & .4065528 & .4913034 & 0 & 1 \\
\hline $\mathrm{BH} \times$ US Pres. Visit & 2167 & .3114905 & .4632097 & 0 & 1 \\
\hline $\mathrm{BH} \times$ Rebase Economy & 2167 & .0516844 & .2214401 & 0 & 1 \\
\hline $\mathrm{BH} \times$ Bring back our girls & 2167 & .0046147 & .0677901 & 0 & 1 \\
\hline $\mathrm{BH} \times$ Ebola crisis & 2167 & .1130595 & .3167386 & 0 & 1 \\
\hline \multicolumn{6}{|l|}{$\begin{array}{l}\text { Precision of reported } \\
\text { military attack in media }\end{array}$} \\
\hline Media source included date & 2167 & .9593909 & .1974285 & 0 & 1 \\
\hline Media source included week & 2167 & .0359945 & .1863193 & 0 & 1 \\
\hline \multicolumn{6}{|c|}{ Attack type dummies } \\
\hline $\begin{array}{l}\text { Battle: Govt regains } \\
\text { territory }\end{array}$ & 2167 & .0046147 & .0677901 & 0 & 1 \\
\hline $\begin{array}{l}\text { Battle: No change of } \\
\text { territory }\end{array}$ & 2167 & .340563 & .4740079 & 0 & 1 \\
\hline $\begin{array}{l}\text { Battle: Non-state actor } \\
\text { overtakes territory }\end{array}$ & 2167 & .0027688 & .0525587 & 0 & 1 \\
\hline $\begin{array}{l}\text { Headquarters/base } \\
\text { established }\end{array}$ & 2167 & .0027688 & .0525587 & 0 & 1 \\
\hline $\begin{array}{l}\text { Non-violent activity by } \\
\text { conflict actor }\end{array}$ & 2167 & .0738348 & .2615622 & 0 & 1 \\
\hline $\begin{array}{l}\text { Non-violent transfer of } \\
\text { territory }\end{array}$ & 2167 & .0221504 & .1472066 & 0 & 1 \\
\hline Remote violence & 2167 & .141209 & .3483174 & 0 & 1 \\
\hline Riots/protests & 2167 & 0 & 0 & 0 & 0 \\
\hline Violence against civilians & 2167 & .4120904 & .4923249 & 0 & 1 \\
\hline Ramadan & 2167 & .1762806 & .3811467 & 0 & 1 \\
\hline BECE & 2167 & .1836641 & .3872994 & 0 & 1 \\
\hline
\end{tabular}


Notes: BH: Boko Haram. AS: Al Shabaab. Since the post-2011 election variables occur after the election, they are considered to be interacted with the election. Flash floods: the 2012 flash flooding in Nigeria (on and after July 2, 2012 until $26^{\text {th }}$ June 2013). US Pres. Visit: visit of President Barack Obama to Africa ( $27^{\text {th }}$ June 2013 until $2^{\text {nd }}$ July 2013). Rebase Economy: rebased Nigeria's economy to become the largest in Africa ( $7^{\text {th }}$ April 2014 until $13^{\text {th }}$ April 2014). Bring back our girls campaign: global media response to Boko Haram (14 April 2014 to July 19, 2014). Ebola crisis in Nigeria (July 20, 2014 - October 20,2014). Media precision of reported military attack rating: the most precise media sources include a specific date of the attack. The second most precise media sources include the specific week of the attack. 
Table 3: Boko Haram interacted with Attention Shocks and Terrorist Fatalities relative to Al Shabaab

\begin{tabular}{|c|c|c|c|c|c|}
\hline Variables & $\begin{array}{c}(1) \\
\text { Fatalities } \\
\end{array}$ & $\begin{array}{c}(2) \\
\text { Fatalities } \\
\end{array}$ & $\begin{array}{c}(3) \\
\text { Fatalities } \\
\end{array}$ & $\begin{array}{c}(4) \\
\text { Fatalities } \\
\end{array}$ & $\begin{array}{c}5) \\
\text { Fatalities } \\
\end{array}$ \\
\hline $\mathrm{BH} \times$ Flash floods & & $\begin{array}{l}-0.237 \\
(1.505)\end{array}$ & $\begin{array}{l}-0.237 \\
(1.505)\end{array}$ & $\begin{array}{l}-0.237 \\
(1.505)\end{array}$ & $\begin{array}{l}-0.395 \\
(1.531)\end{array}$ \\
\hline $\mathrm{BH} \times$ US Pres. Visit & & $\begin{array}{l}0.0920 \\
(1.482)\end{array}$ & $\begin{array}{l}0.0920 \\
(1.482)\end{array}$ & $\begin{array}{l}0.0920 \\
(1.482)\end{array}$ & $\begin{array}{c}-0.0333 \\
(1.486)\end{array}$ \\
\hline BH $\times$ Rebase Economy & & $\begin{array}{c}11.68 * * * \\
(1.995)\end{array}$ & $\begin{array}{c}11.68 * * * \\
(1.995)\end{array}$ & $\begin{array}{c}11.68 * * * \\
(1.995)\end{array}$ & $\begin{array}{c}11.66 * * * * \\
(1.972)\end{array}$ \\
\hline $\mathrm{BH} \times$ Bring back our girls & & $\begin{array}{c}12.01 \\
(7.524)\end{array}$ & $\begin{array}{c}12.01 \\
(7.524)\end{array}$ & $\begin{array}{l}12.01 \\
(7.524)\end{array}$ & $\begin{array}{l}12.07 \\
(7.644)\end{array}$ \\
\hline $\mathrm{BH} \times$ Ebola crisis & & $\begin{array}{c}13.97 * * * \\
(2.265)\end{array}$ & $\begin{array}{c}13.97 * * * \\
(2.265)\end{array}$ & $\begin{array}{c}13.97 * * * \\
(2.265)\end{array}$ & $\begin{array}{c}13.83 * * * * \\
(2.257)\end{array}$ \\
\hline Flash floods & $\begin{array}{c}2.319 * * * \\
(0.698)\end{array}$ & $\begin{array}{c}2.423 * * * \\
(0.718)\end{array}$ & $\begin{array}{c}2.423 * * * \\
(0.718)\end{array}$ & $\begin{array}{c}2.423 * * * \\
(0.718)\end{array}$ & $\begin{array}{c}2.450 * * * * \\
(0.741)\end{array}$ \\
\hline US Pres. Visit & $\begin{array}{c}2.401 * * * \\
(0.730)\end{array}$ & $\begin{array}{c}2.506^{* * * *} \\
(0.751)\end{array}$ & $\begin{array}{c}2.506^{* * *} \\
(0.751)\end{array}$ & $\begin{array}{c}2.506 * * * \\
(0.751)\end{array}$ & $\begin{array}{c}2.545 * * * \\
(0.734)\end{array}$ \\
\hline Rebase Economy & $\begin{array}{l}4.208 * * \\
(1.616)\end{array}$ & $\begin{array}{l}-1.163 \\
(1.413)\end{array}$ & $\begin{array}{l}-1.163 \\
(1.413)\end{array}$ & $\begin{array}{l}-1.163 \\
(1.413)\end{array}$ & $\begin{array}{l}-1.212 \\
(1.460)\end{array}$ \\
\hline Bring back our girls & $\begin{array}{c}5.796 \\
(4.805)\end{array}$ & $\begin{array}{l}-1.241 \\
(1.959)\end{array}$ & $\begin{array}{l}-1.241 \\
(1.959)\end{array}$ & $\begin{array}{l}-1.241 \\
(1.959)\end{array}$ & $\begin{array}{l}-1.363 \\
(2.014)\end{array}$ \\
\hline Ebola crisis & $\begin{array}{l}5.416^{* * * *} \\
(1.812)\end{array}$ & $\begin{array}{l}-1.820 \\
(1.681)\end{array}$ & $\begin{array}{l}-1.820 \\
(1.681)\end{array}$ & $\begin{array}{l}-1.820 \\
(1.681)\end{array}$ & $\begin{array}{l}-1.855 \\
(1.732)\end{array}$ \\
\hline BH & $\begin{array}{c}6.484 * * * \\
(0.831)\end{array}$ & $\begin{array}{c}3.861^{* * * *} \\
(1.320)\end{array}$ & $\begin{array}{c}3.861^{* * * *} \\
(1.320)\end{array}$ & $\begin{array}{c}3.861 * * * \\
(1.320)\end{array}$ & $\begin{array}{c}4.036 * * * * \\
(1.315)\end{array}$ \\
\hline $\begin{array}{l}\text { Battle: Govt regains } \\
\text { territory }\end{array}$ & $\begin{array}{l}15.10 * * \\
(7.319)\end{array}$ & $\begin{array}{l}15.59 * * \\
(7.476)\end{array}$ & $\begin{array}{l}15.59 * * \\
(7.476)\end{array}$ & $\begin{array}{l}15.59 * * \\
(7.476)\end{array}$ & $\begin{array}{l}14.89 * * \\
(7.319)\end{array}$ \\
\hline $\begin{array}{l}\text { Battle: No change of } \\
\text { territory }\end{array}$ & $\begin{array}{l}4.286^{* * *} \\
(2.062)\end{array}$ & $\begin{array}{l}5.483 * * \\
(2.646)\end{array}$ & $\begin{array}{l}5.483^{* *} \\
(2.646)\end{array}$ & $\begin{array}{l}5.483^{* *} \\
(2.646)\end{array}$ & $\begin{array}{l}4.794 * \\
(2.400)\end{array}$ \\
\hline $\begin{array}{l}\text { Headquarters/base } \\
\text { established }\end{array}$ & $\begin{array}{c}3.081 \\
(1.920)\end{array}$ & $\begin{array}{l}4.504 * \\
(2.596)\end{array}$ & $\begin{array}{l}4.504^{*} \\
(2.596)\end{array}$ & $\begin{array}{l}4.504^{*} \\
(2.596)\end{array}$ & $\begin{array}{c}3.803 \\
(2.358)\end{array}$ \\
\hline $\begin{array}{l}\text { Non-violent activity by } \\
\text { conflict actor }\end{array}$ & $\begin{array}{l}0.578 \\
(1.802)\end{array}$ & $\begin{array}{l}2.263 \\
(2.434)\end{array}$ & $\begin{array}{l}2.263 \\
(2.434)\end{array}$ & $\begin{array}{l}2.263 \\
(2.434)\end{array}$ & $\begin{array}{l}1.677 \\
(2.218)\end{array}$ \\
\hline $\begin{array}{l}\text { Non-violent transfer of } \\
\text { territory }\end{array}$ & $\begin{array}{l}0.981 \\
(1.504)\end{array}$ & $\begin{array}{l}2.913 \\
(2.396)\end{array}$ & $\begin{array}{l}2.913 \\
(2.396)\end{array}$ & $\begin{array}{l}2.913 \\
(2.396)\end{array}$ & $\begin{array}{l}2.225 \\
(2.176)\end{array}$ \\
\hline Remote violence & $\begin{array}{c}3.777 * * \\
(1.825)\end{array}$ & $\begin{array}{c}5.644 * * \\
(2.585)\end{array}$ & $\begin{array}{l}5.644 * * \\
(2.585)\end{array}$ & $\begin{array}{l}5.644^{* * *} \\
(2.585)\end{array}$ & $\begin{array}{l}4.935^{* *} \\
(2.305)\end{array}$ \\
\hline Riots/protests & - & - & - & - & - \\
\hline Violence against civilians & $\begin{array}{c}3.652 \\
(2.250)\end{array}$ & $\begin{array}{l}5.451 * \\
(2.876)\end{array}$ & $\begin{array}{l}5.451^{*} \\
(2.876)\end{array}$ & $\begin{array}{l}5.451^{*} \\
(2.876)\end{array}$ & $\begin{array}{l}4.796^{*} \\
(2.613)\end{array}$ \\
\hline Year 2011 dummy & $\begin{array}{l}-2.605 \\
(2.168)\end{array}$ & $\begin{array}{l}-3.137 \\
(2.172)\end{array}$ & $\begin{array}{l}-3.137 \\
(2.172)\end{array}$ & $\begin{array}{l}-3.137 \\
(2.172)\end{array}$ & $\begin{array}{l}-3.225 \\
(2.256)\end{array}$ \\
\hline
\end{tabular}




\begin{tabular}{lccccc} 
Year 2012 dummy & $-4.231 * *$ & $-4.446 * *$ & $-4.446^{* *}$ & $-4.446 * *$ & $-4.535^{* * *}$ \\
& $(1.859)$ & $(1.964)$ & $(1.964)$ & $(1.964)$ & $(2.040)$ \\
Year 2013 dummy & $-2.348^{*}$ & $-2.885^{* *}$ & $-2.885^{* *}$ & $-2.885^{* * *}$ & $-2.986^{* * *}$ \\
& $(1.241)$ & $(1.152)$ & $(1.152)$ & $(1.152)$ & $(1.209)$ \\
Media source included & & & & & 1.554 \\
date & & & & & 0.212 \\
Media source included & & & & & $1.085)$ \\
week & -1.531 & -1.912 & -1.912 & -1.912 & -2.707 \\
Constant & $(1.519)$ & $(1.370)$ & $(1.370)$ & $(1.370)$ & $(1.677)$ \\
& & & & & \\
& 2,167 & 2,167 & 2,167 & 2,167 & 2,167 \\
$\begin{array}{l}\text { Observations } \\
\text { R-squared }\end{array}$ & 0.101 & 0.133 & 0.133 & 0.133 & 0.134 \\
\hline
\end{tabular}

Notes: Robust standard errors in parentheses, with clustering at the level of administrative units. BH: Boko Haram. AS: Al Shabaab. Media precision of reported military attack rating: the most precise media sources include a specific date of the attack. The second most precise media sources include the specific week of the attack. ***Significant at 1 percent, **Significant at 5 percent, *Significant at 10 percent. 
Table 4: Boko Haram Fatalities During Events and the BECE relative to Al Shabaab

\begin{tabular}{|c|c|c|c|c|c|}
\hline Variables & $\begin{array}{c}(1) \\
\text { Fatalities }\end{array}$ & $\begin{array}{c}(2) \\
\text { Fatalities }\end{array}$ & $\begin{array}{c}(3) \\
\text { Fatalities }\end{array}$ & $\begin{array}{c}(4) \\
\text { Fatalities }\end{array}$ & $\begin{array}{c}(5) \\
\text { Fatalities } \\
\end{array}$ \\
\hline $\mathrm{BH} \times$ Flash floods & & $\begin{array}{l}-0.222 \\
(1.481)\end{array}$ & $\begin{array}{l}-0.104 \\
(1.636)\end{array}$ & $\begin{array}{l}-0.104 \\
(1.636)\end{array}$ & $\begin{array}{l}-0.283 \\
(1.653)\end{array}$ \\
\hline $\mathrm{BH} \times$ US Pres. Visit & & $\begin{array}{l}0.0842 \\
(1.474)\end{array}$ & $\begin{array}{l}0.0795 \\
(1.477)\end{array}$ & $\begin{array}{c}0.0795 \\
(1.477)\end{array}$ & $\begin{array}{r}-0.0483 \\
(1.481)\end{array}$ \\
\hline $\mathrm{BH} \times$ Rebase Economy & & $\begin{array}{l}11.66 * * * \\
(2.003)\end{array}$ & $\begin{array}{c}11.67 * * * \\
(2.009)\end{array}$ & $\begin{array}{c}11.67 * * * * \\
(2.009)\end{array}$ & $\begin{array}{c}11.65 * * * \\
(1.984)\end{array}$ \\
\hline $\mathrm{BH} \times$ Bring back our girls & & $\begin{array}{c}11.99 \\
(7.536)\end{array}$ & $\begin{array}{c}11.99 \\
(7.552)\end{array}$ & $\begin{array}{c}11.99 \\
(7.552)\end{array}$ & $\begin{array}{c}12.04 \\
(7.677)\end{array}$ \\
\hline $\mathrm{BH} \times$ Ebola crisis & & $\begin{array}{c}13.72^{* * * *} \\
(2.402)\end{array}$ & $\begin{array}{c}13.47^{* * * *} \\
(3.635)\end{array}$ & $\begin{array}{c}13.47 * * * \\
(3.635)\end{array}$ & $\begin{array}{c}13.30 * * * * \\
(3.633)\end{array}$ \\
\hline $\mathrm{BH} \times \mathrm{BECE} 2011$ & & & $\begin{array}{c}-2.979^{* *} \\
(1.428)\end{array}$ & $\begin{array}{c}-2.979 * * \\
(1.428)\end{array}$ & $\begin{array}{l}-3.013^{*} \\
(1.529)\end{array}$ \\
\hline $\mathrm{BH} \times \mathrm{BECE} 2012$ & & & $\begin{array}{l}1.923 \\
(1.422)\end{array}$ & $\begin{array}{c}1.923 \\
(1.422)\end{array}$ & $\begin{array}{c}1.892 \\
(1.420)\end{array}$ \\
\hline $\mathrm{BH} \times \mathrm{BECE} 2013$ & & & $\begin{array}{c}0.109 \\
(1.210)\end{array}$ & $\begin{array}{c}0.109 \\
(1.210)\end{array}$ & $\begin{array}{l}0.0810 \\
(1.192)\end{array}$ \\
\hline $\mathrm{BH} \times \mathrm{BECE} 2014$ & & & $\begin{array}{c}0.638 \\
(5.126)\end{array}$ & $\begin{array}{c}0.638 \\
(5.126)\end{array}$ & $\begin{array}{c}0.649 \\
(5.152)\end{array}$ \\
\hline BECE2011 & & & $\begin{array}{l}-0.823 \\
(0.687)\end{array}$ & $\begin{array}{l}-1.786^{*} \\
(0.953)\end{array}$ & $\begin{array}{l}-1.790 * \\
(0.950)\end{array}$ \\
\hline BECE2012 & & $\begin{array}{l}2.046 * \\
(1.144)\end{array}$ & $\begin{array}{r}-0.0537 \\
(0.508)\end{array}$ & $\begin{array}{c}-1.017^{*} \\
(0.548)\end{array}$ & $\begin{array}{c}-1.001 * \\
(0.544)\end{array}$ \\
\hline BECE2013 & & $\begin{array}{c}0.626 \\
(0.741)\end{array}$ & $\begin{array}{c}-1.034 \\
(0.991)\end{array}$ & $\begin{array}{c}-1.997 * * \\
(0.940)\end{array}$ & $\begin{array}{c}-1.999 * * \\
(0.923)\end{array}$ \\
\hline BECE2014 & & $\begin{array}{c}2.936 \\
(2.871)\end{array}$ & $\begin{array}{l}0.963^{*} \\
(0.524)\end{array}$ & & \\
\hline BECE & & $\begin{array}{c}-1.625 * * \\
(0.749)\end{array}$ & & $\begin{array}{l}0.963 * \\
(0.524)\end{array}$ & $\begin{array}{l}0.964 * \\
(0.518)\end{array}$ \\
\hline Flash floods & $\begin{array}{c}2.319 * * * \\
(0.698)\end{array}$ & $\begin{array}{c}2.752^{* * * *} \\
(0.830)\end{array}$ & $\begin{array}{c}2.719 * * * \\
(0.820)\end{array}$ & $\begin{array}{c}2.719 * * * \\
(0.820)\end{array}$ & $\begin{array}{c}2.731 * * * * \\
(0.839)\end{array}$ \\
\hline US Pres. Visit & $\begin{array}{c}2.401^{* * * *} \\
(0.730)\end{array}$ & $\begin{array}{l}2.904 * * * \\
(0.833)\end{array}$ & $\begin{array}{c}2.917 * * * \\
(0.830)\end{array}$ & $\begin{array}{l}2.917 * * * * \\
(0.830)\end{array}$ & $\begin{array}{c}2.951 * * * * \\
(0.816)\end{array}$ \\
\hline Rebase Economy & $\begin{array}{l}4.208 * * \\
(1.616)\end{array}$ & $\begin{array}{l}-1.100 \\
(1.445)\end{array}$ & $\begin{array}{l}-1.106 \\
(1.454)\end{array}$ & $\begin{array}{l}-1.106 \\
(1.454)\end{array}$ & $\begin{array}{l}-1.157 \\
(1.504)\end{array}$ \\
\hline Bring back our girls & $\begin{array}{c}5.796 \\
(4.805)\end{array}$ & $\begin{array}{c}-1.208 \\
(1.946)\end{array}$ & $\begin{array}{l}-1.204 \\
(1.948)\end{array}$ & $\begin{array}{c}-1.204 \\
(1.948)\end{array}$ & $\begin{array}{l}-1.309 \\
(2.010)\end{array}$ \\
\hline Ebola crisis & $\begin{array}{c}5.416^{* * * *} \\
(1.812)\end{array}$ & $\begin{array}{l}-2.199 \\
(2.221)\end{array}$ & $\begin{array}{l}-2.084 \\
(1.669)\end{array}$ & $\begin{array}{l}-2.084 \\
(1.669)\end{array}$ & $\begin{array}{l}-2.115 \\
(1.721)\end{array}$ \\
\hline $\mathrm{BH}$ & $\begin{array}{c}6.484 * * * \\
(0.831)\end{array}$ & $\begin{array}{c}3.892^{* * * *} \\
(1.312)\end{array}$ & $\begin{array}{c}3.898 * * * * \\
(1.318)\end{array}$ & $\begin{array}{c}3.898 * * * \\
(1.318)\end{array}$ & $\begin{array}{c}4.076 * * * \\
(1.311)\end{array}$ \\
\hline $\begin{array}{l}\text { Battle: Govt regains } \\
\text { territory }\end{array}$ & $\begin{array}{l}15.10^{* * *} \\
(7.319)\end{array}$ & $\begin{array}{l}15.77 * * \\
(7.364)\end{array}$ & $\begin{array}{l}15.75 * * \\
(7.317)\end{array}$ & $\begin{array}{l}15.75^{* *} * \\
(7.317)\end{array}$ & $\begin{array}{l}15.34 * * \\
(7.148)\end{array}$ \\
\hline Battle: No change of & $4.286 * *$ & $5.595 * *$ & $5.557 * *$ & $5.557 * *$ & $5.163 * *$ \\
\hline
\end{tabular}




\begin{tabular}{|c|c|c|c|c|c|}
\hline territory & $(2.062)$ & $(2.437)$ & (2.339) & (2.339) & $(1.933)$ \\
\hline Battle: Non-state & 3.081 & $4.422 *$ & $4.635^{*}$ & $4.635^{*}$ & $4.214 * *$ \\
\hline $\begin{array}{l}\text { actor overtakes } \\
\text { territory }\end{array}$ & $(1.920)$ & (2.412) & $(2.353)$ & $(2.353)$ & $(1.950)$ \\
\hline $\begin{array}{l}\text { Non-violent activity by } \\
\text { a conflict actor }\end{array}$ & $\begin{array}{c}0.578 \\
(1.802)\end{array}$ & $\begin{array}{c}2.416 \\
(2.235)\end{array}$ & $\begin{array}{c}2.382 \\
(2.132)\end{array}$ & $\begin{array}{c}2.382 \\
(2.132)\end{array}$ & $\begin{array}{c}2.025 \\
(1.752)\end{array}$ \\
\hline Non-violent transfer & 0.981 & 3.054 & 3.040 & 3.040 & 2.642 \\
\hline of territory & $(1.504)$ & $(2.228)$ & $(2.146)$ & $(2.146)$ & $(1.767)$ \\
\hline Remote violence & $\begin{array}{l}3.777 * * \\
(1.825)\end{array}$ & $\begin{array}{l}5.762 * * \\
(2.409)\end{array}$ & $\begin{array}{l}5.720 * * \\
(2.335)\end{array}$ & $\begin{array}{l}5.720 * * \\
(2.335)\end{array}$ & $\begin{array}{c}5.310 * * * * \\
(1.922)\end{array}$ \\
\hline Violence against & 3.652 & $5.538 * *$ & $5.476 * *$ & $5.476^{* *}$ & $5.103^{* *}$ \\
\hline civilians & $(2.250)$ & (2.688) & $(2.626)$ & $(2.626)$ & $(2.231)$ \\
\hline Year 2011 dummy & $\begin{array}{l}-2.605 \\
(2.168)\end{array}$ & $\begin{array}{l}-3.042 \\
(2.170)\end{array}$ & $\begin{array}{l}-3.050 \\
(2.162)\end{array}$ & $\begin{array}{l}-3.050 \\
(2.162)\end{array}$ & $\begin{array}{l}-3.146 \\
(2.247)\end{array}$ \\
\hline Year 2012 dummy & $\begin{array}{c}-4.231^{* *} \\
(1.859)\end{array}$ & $\begin{array}{c}-4.852 * * \\
(2.059)\end{array}$ & $\begin{array}{c}-4.871 * * \\
(2.047)\end{array}$ & $\begin{array}{l}-4.871 * * \\
(2.047)\end{array}$ & $\begin{array}{c}-4.955 * * \\
(2.113)\end{array}$ \\
\hline Year 2013 dummy & $\begin{array}{l}-2.348^{*} \\
(1.241)\end{array}$ & $\begin{array}{c}-3.050 * * \\
(1.160)\end{array}$ & $\begin{array}{c}-3.060 * * \\
(1.151)\end{array}$ & $\begin{array}{c}-3.060 * * \\
(1.151)\end{array}$ & $\begin{array}{c}-3.152 * * \\
(1.202)\end{array}$ \\
\hline $\begin{array}{l}\text { Media source included } \\
\text { date }\end{array}$ & & & & & $\begin{array}{l}-0.210 \\
(0.901)\end{array}$ \\
\hline $\begin{array}{l}\text { Media source included } \\
\text { week }\end{array}$ & & & & & $\begin{array}{c}-1.538 * * \\
(0.648)\end{array}$ \\
\hline Constant & $\begin{array}{l}-1.531 \\
(1.519)\end{array}$ & $\begin{array}{l}-2.050 \\
(1.234)\end{array}$ & $\begin{array}{l}-1.999 \\
(1.202)\end{array}$ & $\begin{array}{l}-1.999 \\
(1.202)\end{array}$ & $\begin{array}{l}-1.314 \\
(1.424)\end{array}$ \\
\hline Observations & 2,167 & 2,167 & 2,167 & 2,167 & 2,167 \\
\hline R-squared & 0.101 & 0.134 & 0.135 & 0.135 & 0.135 \\
\hline
\end{tabular}


Table 5: Boko Haram Fatalities During Attention Shocks, BECE and Ramadan Relative to all other armed groups in Nigeria and Somalia

\begin{tabular}{|c|c|c|c|c|}
\hline Variables & $\begin{array}{c}(1) \\
\text { Fatalities }\end{array}$ & $\begin{array}{c}(2) \\
\text { Fatalities }\end{array}$ & $\begin{array}{c}\text { (3) } \\
\text { Fatalities }\end{array}$ & $\begin{array}{c}(4) \\
\text { fatalities }\end{array}$ \\
\hline $\operatorname{Ram} \times \mathrm{BH}$ & $\begin{array}{c}1.137 \\
(1.197)\end{array}$ & $\begin{array}{l}1.233 \\
(1.485)\end{array}$ & $\begin{array}{l}1.233 \\
(1.485)\end{array}$ & $\begin{array}{c}1.477 \\
(1.554)\end{array}$ \\
\hline $\operatorname{Ram} \times$ AS & $\begin{array}{l}0.916 \\
(0.739)\end{array}$ & $\begin{array}{c}0.929 \\
(0.740)\end{array}$ & $\begin{array}{c}0.929 \\
(0.740)\end{array}$ & $\begin{array}{c}0.923 \\
(0.757)\end{array}$ \\
\hline Ram & $\begin{array}{c}-0.830 * * * \\
(0.265)\end{array}$ & $\begin{array}{c}-0.835^{* * * *} \\
(0.271)\end{array}$ & $\begin{array}{c}-0.835 * * * \\
(0.271)\end{array}$ & $\begin{array}{c}-0.818 * * * \\
(0.265)\end{array}$ \\
\hline $\mathrm{BH} \times$ Flash floods & $\begin{array}{c}0.308 \\
(1.469)\end{array}$ & $\begin{array}{c}0.378 \\
(1.650)\end{array}$ & $\begin{array}{c}0.378 \\
(1.650)\end{array}$ & $\begin{array}{c}0.948 \\
(1.683)\end{array}$ \\
\hline $\mathrm{BH} \times$ US Pres. Visit & $\begin{array}{c}0.700 \\
(1.494)\end{array}$ & $\begin{array}{l}0.668 \\
(1.483)\end{array}$ & $\begin{array}{l}0.668 \\
(1.483)\end{array}$ & $\begin{array}{l}1.028 \\
(1.565)\end{array}$ \\
\hline BH $\times$ Rebase Economy & $\begin{array}{c}11.31 * * * \\
(1.771)\end{array}$ & $\begin{array}{c}11.34 * * * \\
(1.711)\end{array}$ & $\begin{array}{c}11.34 * * * \\
(1.711)\end{array}$ & $\begin{array}{c}11.55^{* * * *} \\
(1.774)\end{array}$ \\
\hline $\begin{array}{l}\mathrm{BH} \times \text { Bring back our } \\
\text { girls }\end{array}$ & $\begin{array}{l}12.86^{*} \\
(7.439)\end{array}$ & $\begin{array}{l}12.89 * \\
(7.507)\end{array}$ & $\begin{array}{l}12.89^{*} \\
(7.507)\end{array}$ & $\begin{array}{l}13.01^{*} \\
(7.300)\end{array}$ \\
\hline $\mathrm{BH} \times$ Ebola crisis & $\begin{array}{c}12.97 * * * * \\
(2.257)\end{array}$ & $\begin{array}{c}12.40 * * * * \\
(3.680)\end{array}$ & $\begin{array}{c}12.40 * * * * \\
(3.680)\end{array}$ & $\begin{array}{c}12.76 * * * * \\
(3.615)\end{array}$ \\
\hline BH $\times$ BECE2011 & & $\begin{array}{l}-2.329 \\
(1.653)\end{array}$ & $\begin{array}{l}-2.329 \\
(1.653)\end{array}$ & $\begin{array}{l}-2.434 \\
(1.778)\end{array}$ \\
\hline BH $\times$ BECE2012 & & $\begin{array}{l}1.699 \\
(1.532)\end{array}$ & $\begin{array}{l}1.699 \\
(1.532)\end{array}$ & $\begin{array}{l}1.745 \\
(1.544)\end{array}$ \\
\hline BH $\times$ BECE2013 & & $\begin{array}{c}0.494 \\
(0.839)\end{array}$ & $\begin{array}{c}0.494 \\
(0.839)\end{array}$ & $\begin{array}{c}0.729 \\
(0.923)\end{array}$ \\
\hline BH $\times$ BECE2014 & & $\begin{array}{c}1.197 \\
(5.045)\end{array}$ & $\begin{array}{l}1.197 \\
(5.045)\end{array}$ & $\begin{array}{c}1.252 \\
(5.007)\end{array}$ \\
\hline BECE2011 & & $\begin{array}{l}-0.789 \\
(0.742)\end{array}$ & - & - \\
\hline BECE2012 & $\begin{array}{c}0.935 \\
(0.821)\end{array}$ & $\begin{array}{l}-0.220 \\
(0.315)\end{array}$ & $\begin{array}{c}0.568 \\
(0.766)\end{array}$ & $\begin{array}{c}0.589 \\
(0.766)\end{array}$ \\
\hline BECE2013 & $\begin{array}{c}0.836 \\
(0.764)\end{array}$ & $\begin{array}{l}-0.238 \\
(0.354)\end{array}$ & $\begin{array}{c}0.551 \\
(0.807)\end{array}$ & $\begin{array}{l}0.488 \\
(0.824)\end{array}$ \\
\hline BECE2014 & $\begin{array}{l}1.677 \\
(1.118)\end{array}$ & $\begin{array}{c}0.544 \\
(0.551)\end{array}$ & $\begin{array}{l}1.333 \\
(1.019)\end{array}$ & $\begin{array}{l}1.348 \\
(1.025)\end{array}$ \\
\hline BECE & $\begin{array}{l}-1.058 \\
(0.742)\end{array}$ & & $\begin{array}{l}-0.789 \\
(0.742)\end{array}$ & $\begin{array}{l}-0.800 \\
(0.740)\end{array}$ \\
\hline Flash floods & $\begin{array}{c}0.516 \\
(0.570)\end{array}$ & $\begin{array}{c}0.509 \\
(0.587)\end{array}$ & $\begin{array}{c}0.509 \\
(0.587)\end{array}$ & $\begin{array}{c}0.492 \\
(0.594)\end{array}$ \\
\hline US Pres. Visit & $\begin{array}{c}0.650 \\
(0.597)\end{array}$ & $\begin{array}{c}0.650 \\
(0.595)\end{array}$ & $\begin{array}{c}0.650 \\
(0.595)\end{array}$ & $\begin{array}{c}0.625 \\
(0.606)\end{array}$ \\
\hline Rebase Economy & -0.330 & -0.331 & -0.331 & -0.314 \\
\hline
\end{tabular}




\begin{tabular}{|c|c|c|c|c|}
\hline & $(0.598)$ & $(0.600)$ & $(0.600)$ & $(0.575)$ \\
\hline \multirow[t]{2}{*}{ Bring back our girls } & -1.589 & -1.590 & -1.590 & -1.562 \\
\hline & $(1.055)$ & $(1.057)$ & $(1.057)$ & (1.019) \\
\hline \multirow[t]{2}{*}{ Ebola crisis } & -0.594 & -0.567 & -0.567 & -0.520 \\
\hline & $(0.978)$ & $(0.902)$ & $(0.902)$ & $(0.864)$ \\
\hline \multirow[t]{2}{*}{$\mathrm{BH}$} & $2.962 * *$ & $2.935^{* * *}$ & $2.935 * *$ & 2.400 \\
\hline & $(1.405)$ & $(1.456)$ & $(1.456)$ & $(1.621)$ \\
\hline \multirow[t]{2}{*}{ AS } & -0.538 & -0.549 & -0.549 & -0.506 \\
\hline & $(0.625)$ & $(0.627)$ & $(0.627)$ & $(0.611)$ \\
\hline \multirow[t]{2}{*}{ Govt regains territory } & -2.337 & -2.335 & -2.335 & -2.497 \\
\hline & $(2.615)$ & $(2.616)$ & $(2.616)$ & $(2.728)$ \\
\hline \multirow{2}{*}{ No change of territory } & $-5.373 * *$ & $-5.374 * *$ & $-5.374 * *$ & $-5.281 * *$ \\
\hline & $(2.463)$ & $(2.456)$ & $(2.456)$ & $(2.488)$ \\
\hline \multirow{2}{*}{$\begin{array}{l}\text { Headquarters/base } \\
\text { established }\end{array}$} & $-8.431 * * *$ & $-8.415^{* * * *}$ & $-8.415 * * *$ & $-8.631 * * *$ \\
\hline & $(3.031)$ & $(2.986)$ & (2.986) & $(3.139)$ \\
\hline \multirow{2}{*}{$\begin{array}{l}\text { Non-violent activity } \\
\text { by conflict actor }\end{array}$} & $-7.983^{* * *}$ & $-7.974 * * *$ & $-7.974 * * *$ & $-8.023 * * *$ \\
\hline & $(2.761)$ & $(2.752)$ & $(2.752)$ & $(2.804)$ \\
\hline \multirow{2}{*}{$\begin{array}{l}\text { Non-violent transfer } \\
\text { of territory }\end{array}$} & $-8.274 * * *$ & $-8.264 * * *$ & $-8.264 * * *$ & $-8.382 * * *$ \\
\hline & $(2.910)$ & (2.894) & (2.894) & $(2.956)$ \\
\hline \multirow[t]{2}{*}{ Remote violence } & $-5.872 * *$ & $-5.870 * *$ & $-5.870 * *$ & $-5.753 * *$ \\
\hline & $(2.618)$ & $(2.610)$ & $(2.610)$ & $(2.629)$ \\
\hline \multirow[t]{2}{*}{ Riots/protests } & $-7.893 * * *$ & $-7.893 * * *$ & $-7.893 * * *$ & $-7.803 * * *$ \\
\hline & $(2.883)$ & $(2.875)$ & $(2.875)$ & $(2.898)$ \\
\hline \multirow{2}{*}{$\begin{array}{l}\text { Violence against } \\
\text { civilians }\end{array}$} & $-5.196 *$ & $-5.200 *$ & $-5.200 *$ & $-5.161^{*}$ \\
\hline & $(2.616)$ & $(2.610)$ & $(2.610)$ & $(2.648)$ \\
\hline \multirow[t]{2}{*}{2011} & -1.151 & -1.149 & -1.149 & -1.088 \\
\hline & $(1.313)$ & $(1.311)$ & $(1.311)$ & $(1.244)$ \\
\hline \multirow[t]{2}{*}{2012} & $-1.976^{*}$ & $-1.973 *$ & $-1.973^{*}$ & $-1.904^{*}$ \\
\hline & $(1.129)$ & $(1.120)$ & $(1.120)$ & $(1.076)$ \\
\hline \multirow[t]{2}{*}{2013} & $-1.983 * * *$ & $-1.982 * * *$ & $-1.982 * * *$ & $-1.928 * * *$ \\
\hline & $(0.724)$ & $(0.719)$ & $(0.719)$ & $(0.691)$ \\
\hline \multicolumn{2}{|l|}{ Media source included } & & & -1.096 \\
\hline \multirow{3}{*}{$\begin{array}{l}\text { Media source included } \\
\text { week }\end{array}$} & & & & $(0.822)$ \\
\hline & & & & 2.248 \\
\hline & & & & $(1.723)$ \\
\hline \multirow[t]{2}{*}{ Constant } & $9.131 * *$ & $9.132 * *$ & $9.132 * *$ & $10.02 * * *$ \\
\hline & $(3.451)$ & $(3.444)$ & $(3.444)$ & $(3.323)$ \\
\hline Observations & 13,604 & 13,604 & 13,604 & 13,604 \\
\hline R-squared & 0.050 & 0.050 & 0.050 & 0.053 \\
\hline
\end{tabular}

Notes: Robust standard errors in parentheses, with clustering at the level of administrative units. BH: Boko Haram. AS: Al Shabaab. Media precision of reported military attack rating: the most precise media sources include a specific date of the attack. The second most precise media sources include the specific week of the attack. ***Significant at 1 percent, **Significant at 5 percent, *Significant at 10 percent. 
Table 4: Boko Haram Fatalities During Events and the BECE relative to Al Shabaab

\begin{tabular}{|c|c|c|c|c|c|}
\hline Variables & $\begin{array}{c}\text { (1) } \\
\text { Fatalities }\end{array}$ & $\begin{array}{c}(2) \\
\text { Fatalities }\end{array}$ & $\begin{array}{c}\text { (3) } \\
\text { Fatalities }\end{array}$ & $\begin{array}{c}(4) \\
\text { Fatalities }\end{array}$ & $\begin{array}{c}(5) \\
\text { Fatalities }\end{array}$ \\
\hline $\mathrm{BH} \times$ Flash floods & & $\begin{array}{c}-0.222 \\
(1.481)\end{array}$ & $\begin{array}{c}-0.104 \\
(1.636)\end{array}$ & $\begin{array}{c}-0.104 \\
(1.636)\end{array}$ & $\begin{array}{c}-0.283 \\
(1.653)\end{array}$ \\
\hline $\mathrm{BH} \times$ US Pres. Visit & & $\begin{array}{l}0.0842 \\
(1.474)\end{array}$ & $\begin{array}{l}0.0795 \\
(1.477)\end{array}$ & $\begin{array}{l}0.0795 \\
(1.477)\end{array}$ & $\begin{array}{c}-0.0483 \\
(1.481)\end{array}$ \\
\hline $\mathrm{BH} \times$ Rebase Economy & & $\begin{array}{c}11.66 * * * \\
(2.003)\end{array}$ & $\begin{array}{c}11.67 * * * \\
(2.009)\end{array}$ & $\begin{array}{c}11.67 * * * * \\
(2.009)\end{array}$ & $\begin{array}{c}11.65 * * * \\
(1.984)\end{array}$ \\
\hline $\mathrm{BH} \times$ Bring back our girls & & $\begin{array}{c}11.99 \\
(7.536)\end{array}$ & $\begin{array}{c}11.99 \\
(7.552)\end{array}$ & $\begin{array}{c}11.99 \\
(7.552)\end{array}$ & $\begin{array}{c}12.04 \\
(7.677)\end{array}$ \\
\hline $\mathrm{BH} \times$ Ebola crisis & & $\begin{array}{l}13.72 * * * \\
(2.402)\end{array}$ & $\begin{array}{l}13.47 * * * \\
(3.635)\end{array}$ & $\begin{array}{c}13.47 * * * \\
(3.635)\end{array}$ & $\begin{array}{c}13.30 * * * * \\
(3.633)\end{array}$ \\
\hline $\mathrm{BH} \times \mathrm{BECE} 2011$ & & & $\begin{array}{c}-2.979 * * \\
(1.428)\end{array}$ & $\begin{array}{c}-2.979 * * \\
(1.428)\end{array}$ & $\begin{array}{c}-3.013^{*} \\
(1.529)\end{array}$ \\
\hline $\mathrm{BH} \times \mathrm{BECE} 2012$ & & & $\begin{array}{c}1.923 \\
(1.422)\end{array}$ & $\begin{array}{c}1.923 \\
(1.422)\end{array}$ & $\begin{array}{c}1.892 \\
(1.420)\end{array}$ \\
\hline $\mathrm{BH} \times \mathrm{BECE} 2013$ & & & $\begin{array}{c}0.109 \\
(1.210)\end{array}$ & $\begin{array}{c}0.109 \\
(1.210)\end{array}$ & $\begin{array}{l}0.0810 \\
(1.192)\end{array}$ \\
\hline $\mathrm{BH} \times \mathrm{BECE} 2014$ & & & $\begin{array}{c}0.638 \\
(5.126)\end{array}$ & $\begin{array}{c}0.638 \\
(5.126)\end{array}$ & $\begin{array}{c}0.649 \\
(5.152)\end{array}$ \\
\hline BECE2011 & & & $\begin{array}{l}-0.823 \\
(0.687)\end{array}$ & $\begin{array}{c}-1.786^{*} \\
(0.953)\end{array}$ & $\begin{array}{c}-1.790^{*} \\
(0.950)\end{array}$ \\
\hline BECE2012 & & $\begin{array}{l}2.046 * \\
(1.144)\end{array}$ & $\begin{array}{l}-0.0537 \\
(0.508)\end{array}$ & $\begin{array}{l}-1.017^{*} \\
(0.548)\end{array}$ & $\begin{array}{l}-1.001 * \\
(0.544)\end{array}$ \\
\hline BECE2013 & & $\begin{array}{c}0.626 \\
(0.741)\end{array}$ & $\begin{array}{l}-1.034 \\
(0.991)\end{array}$ & $\begin{array}{c}-1.997 * * \\
(0.940)\end{array}$ & $\begin{array}{c}-1.999 * * \\
(0.923)\end{array}$ \\
\hline BECE2014 & & $\begin{array}{c}2.936 \\
(2.871)\end{array}$ & $\begin{array}{l}0.963 * \\
(0.524)\end{array}$ & & \\
\hline BECE & & $\begin{array}{c}-1.625^{* *} \\
(0.749)\end{array}$ & & $\begin{array}{l}0.963 * \\
(0.524)\end{array}$ & $\begin{array}{l}0.964 * \\
(0.518)\end{array}$ \\
\hline Flash floods & $\begin{array}{l}2.319 * * * \\
(0.698)\end{array}$ & $\begin{array}{l}2.752 * * * \\
(0.830)\end{array}$ & $\begin{array}{l}2.719 * * * \\
(0.820)\end{array}$ & $\begin{array}{l}2.719 * * * \\
(0.820)\end{array}$ & $\begin{array}{c}2.731 * * * \\
(0.839)\end{array}$ \\
\hline US Pres. Visit & $\begin{array}{c}2.401 * * * \\
(0.730)\end{array}$ & $\begin{array}{c}2.904 * * * \\
(0.833)\end{array}$ & $\begin{array}{c}2.917 * * * \\
(0.830)\end{array}$ & $\begin{array}{c}2.917 * * * * \\
(0.830)\end{array}$ & $\begin{array}{c}2.951 * * * \\
(0.816)\end{array}$ \\
\hline Rebase Economy & $\begin{array}{c}4.208 * * \\
(1.616)\end{array}$ & $\begin{array}{l}-1.100 \\
(1.445)\end{array}$ & $\begin{array}{l}-1.106 \\
(1.454)\end{array}$ & $\begin{array}{l}-1.106 \\
(1.454)\end{array}$ & $\begin{array}{l}-1.157 \\
(1.504)\end{array}$ \\
\hline Bring back our girls & $\begin{array}{c}5.796 \\
(4.805)\end{array}$ & $\begin{array}{l}-1.208 \\
(1.946)\end{array}$ & $\begin{array}{l}-1.204 \\
(1.948)\end{array}$ & $\begin{array}{l}-1.204 \\
(1.948)\end{array}$ & $\begin{array}{l}-1.309 \\
(2.010)\end{array}$ \\
\hline Ebola crisis & $\begin{array}{l}5.416^{* * * *} \\
(1.812)\end{array}$ & $\begin{array}{l}-2.199 \\
(2.221)\end{array}$ & $\begin{array}{l}-2.084 \\
(1.669)\end{array}$ & $\begin{array}{l}-2.084 \\
(1.669)\end{array}$ & $\begin{array}{l}-2.115 \\
(1.721)\end{array}$ \\
\hline $\mathrm{BH}$ & $\begin{array}{c}6.484 * * * \\
(0.831)\end{array}$ & $\begin{array}{c}3.892 * * * \\
(1.312)\end{array}$ & $\begin{array}{c}3.898 * * * \\
(1.318)\end{array}$ & $\begin{array}{c}3.898 * * * * \\
(1.318)\end{array}$ & $\begin{array}{c}4.076 * * * * \\
(1.311)\end{array}$ \\
\hline $\begin{array}{l}\text { Battle: Govt regains } \\
\text { territory }\end{array}$ & $\begin{array}{l}15.10 * * \\
(7.319)\end{array}$ & $\begin{array}{l}15.77 * * \\
(7.364)\end{array}$ & $\begin{array}{l}15.75 * * \\
(7.317)\end{array}$ & $\begin{array}{l}15.75 * * \\
(7.317)\end{array}$ & $\begin{array}{l}15.34 * * \\
(7.148)\end{array}$ \\
\hline Battle: No change of & $4.286 * *$ & $5.595 * *$ & $5.557 * *$ & $5.557 * *$ & $5.163 * *$ \\
\hline
\end{tabular}




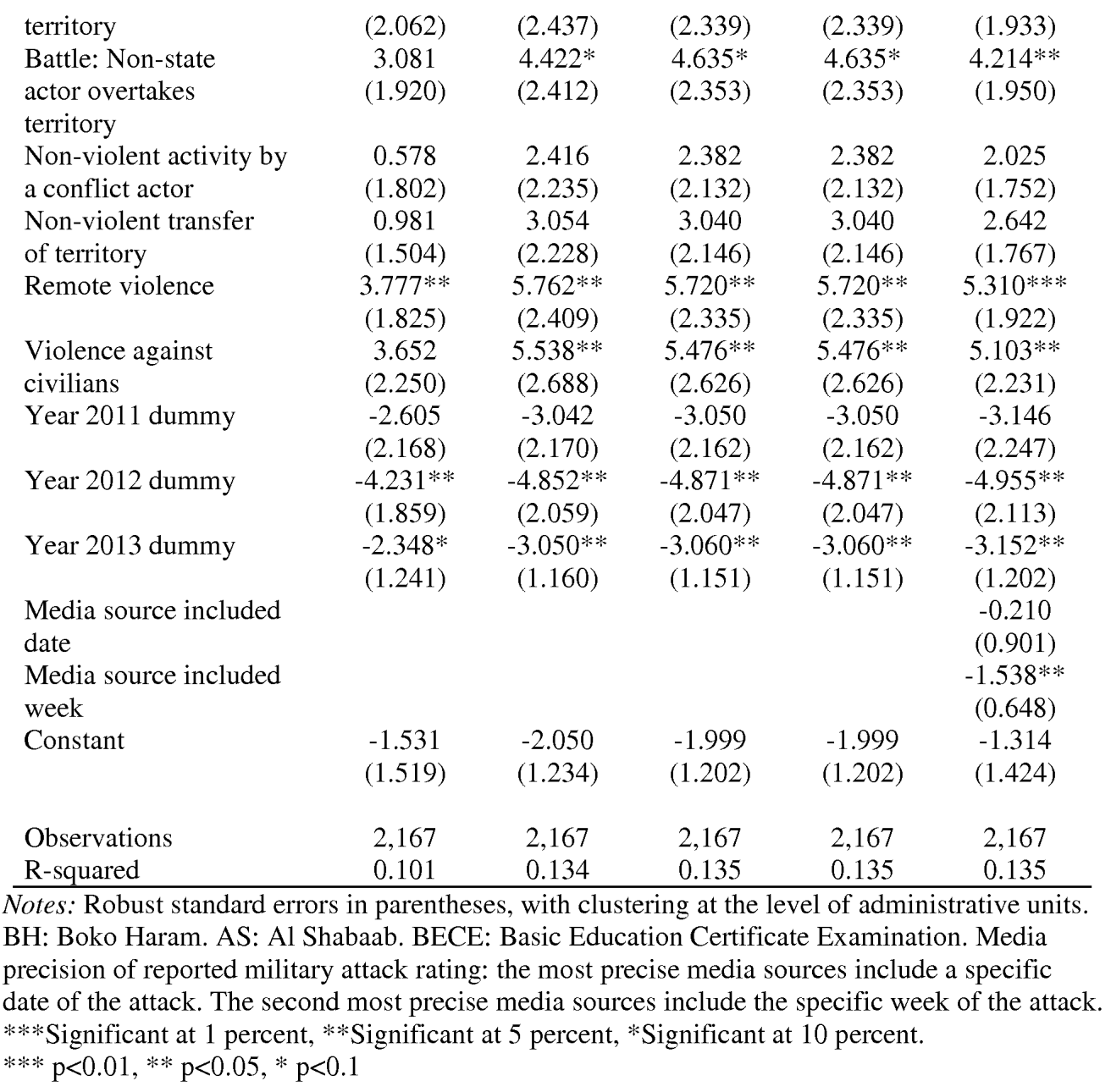


Table 5: Boko Haram Fatalities During Attention Shocks, BECE and Ramadan Relative to all other armed groups in Nigeria and Somalia

\begin{tabular}{|c|c|c|c|c|}
\hline Variables & $\begin{array}{c}(1) \\
\text { Fatalities } \\
\end{array}$ & $\begin{array}{c}(2) \\
\text { Fatalities } \\
\end{array}$ & $\begin{array}{c}(3) \\
\text { Fatalities }\end{array}$ & $\begin{array}{c}(4) \\
\text { fatalities }\end{array}$ \\
\hline $\operatorname{Ram} \times \mathrm{BH}$ & $\begin{array}{c}1.137 \\
(1.197)\end{array}$ & $\begin{array}{c}1.233 \\
(1.485)\end{array}$ & $\begin{array}{c}1.233 \\
(1.485)\end{array}$ & $\begin{array}{c}1.477 \\
(1.554)\end{array}$ \\
\hline $\operatorname{Ram} \times \mathrm{AS}$ & $\begin{array}{c}0.916 \\
(0.739)\end{array}$ & $\begin{array}{c}0.929 \\
(0.740)\end{array}$ & $\begin{array}{c}0.929 \\
(0.740)\end{array}$ & $\begin{array}{c}0.923 \\
(0.757)\end{array}$ \\
\hline Ram & $\begin{array}{c}-0.830 * * * \\
(0.265)\end{array}$ & $\begin{array}{c}-0.835^{* * * *} \\
(0.271)\end{array}$ & $\begin{array}{c}-0.835 * * * \\
(0.271)\end{array}$ & $\begin{array}{l}-0.818 * * * \\
(0.265)\end{array}$ \\
\hline $\mathrm{BH} \times$ Flash floods & $\begin{array}{c}0.308 \\
(1.469)\end{array}$ & $\begin{array}{c}0.378 \\
(1.650)\end{array}$ & $\begin{array}{c}0.378 \\
(1.650)\end{array}$ & $\begin{array}{c}0.948 \\
(1.683)\end{array}$ \\
\hline $\mathrm{BH} \times$ US Pres. Visit & $\begin{array}{c}0.700 \\
(1.494)\end{array}$ & $\begin{array}{c}0.668 \\
(1.483)\end{array}$ & $\begin{array}{c}0.668 \\
(1.483)\end{array}$ & $\begin{array}{c}1.028 \\
(1.565)\end{array}$ \\
\hline BH $\times$ Rebase Economy & $\begin{array}{l}11.31 * * * \\
(1.771)\end{array}$ & $\begin{array}{l}11.34 * * * \\
(1.711)\end{array}$ & $\begin{array}{l}11.34 * * * \\
(1.711)\end{array}$ & $\begin{array}{c}11.55 * * * \\
(1.774)\end{array}$ \\
\hline $\begin{array}{l}\mathrm{BH} \times \text { Bring back our } \\
\text { girls }\end{array}$ & $\begin{array}{l}12.86^{*} \\
(7.439)\end{array}$ & $\begin{array}{l}12.89 * \\
(7.507)\end{array}$ & $\begin{array}{l}12.89^{*} \\
(7.507)\end{array}$ & $\begin{array}{l}13.01^{*} \\
(7.300)\end{array}$ \\
\hline $\mathrm{BH} \times$ Ebola crisis & $\begin{array}{l}12.97 * * * \\
(2.257)\end{array}$ & $\begin{array}{l}12.40 * * * \\
(3.680)\end{array}$ & $\begin{array}{l}12.40 * * * \\
(3.680)\end{array}$ & $\begin{array}{l}12.76 * * * \\
(3.615)\end{array}$ \\
\hline $\mathrm{BH} \times \mathrm{BECE} 2011$ & & $\begin{array}{l}-2.329 \\
(1.653)\end{array}$ & $\begin{array}{l}-2.329 \\
(1.653)\end{array}$ & $\begin{array}{l}-2.434 \\
(1.778)\end{array}$ \\
\hline $\mathrm{BH} \times \mathrm{BECE} 2012$ & & $\begin{array}{c}1.699 \\
(1.532)\end{array}$ & $\begin{array}{c}1.699 \\
(1.532)\end{array}$ & $\begin{array}{c}1.745 \\
(1.544)\end{array}$ \\
\hline $\mathrm{BH} \times \mathrm{BECE} 2013$ & & $\begin{array}{c}0.494 \\
(0.839)\end{array}$ & $\begin{array}{c}0.494 \\
(0.839)\end{array}$ & $\begin{array}{c}0.729 \\
(0.923)\end{array}$ \\
\hline $\mathrm{BH} \times \mathrm{BECE} 2014$ & & $\begin{array}{c}1.197 \\
(5.045)\end{array}$ & $\begin{array}{c}1.197 \\
(5.045)\end{array}$ & $\begin{array}{c}1.252 \\
(5.007)\end{array}$ \\
\hline BECE2011 & & $\begin{array}{l}-0.789 \\
(0.742)\end{array}$ & - & - \\
\hline BECE2012 & $\begin{array}{c}0.935 \\
(0.821)\end{array}$ & $\begin{array}{l}-0.220 \\
(0.315)\end{array}$ & $\begin{array}{c}0.568 \\
(0.766)\end{array}$ & $\begin{array}{c}0.589 \\
(0.766)\end{array}$ \\
\hline BECE2013 & $\begin{array}{c}0.836 \\
(0.764)\end{array}$ & $\begin{array}{l}-0.238 \\
(0.354)\end{array}$ & $\begin{array}{c}0.551 \\
(0.807)\end{array}$ & $\begin{array}{c}0.488 \\
(0.824)\end{array}$ \\
\hline BECE2014 & $\begin{array}{c}1.677 \\
(1.118)\end{array}$ & $\begin{array}{c}0.544 \\
(0.551)\end{array}$ & $\begin{array}{c}1.333 \\
(1.019)\end{array}$ & $\begin{array}{c}1.348 \\
(1.025)\end{array}$ \\
\hline BECE & $\begin{array}{l}-1.058 \\
(0.742)\end{array}$ & & $\begin{array}{l}-0.789 \\
(0.742)\end{array}$ & $\begin{array}{l}-0.800 \\
(0.740)\end{array}$ \\
\hline Flash floods & $\begin{array}{c}0.516 \\
(0.570)\end{array}$ & $\begin{array}{c}0.509 \\
(0.587)\end{array}$ & $\begin{array}{c}0.509 \\
(0.587)\end{array}$ & $\begin{array}{c}0.492 \\
(0.594)\end{array}$ \\
\hline US Pres. Visit & $\begin{array}{c}0.650 \\
(0.597)\end{array}$ & $\begin{array}{c}0.650 \\
(0.595)\end{array}$ & $\begin{array}{c}0.650 \\
(0.595)\end{array}$ & $\begin{array}{c}0.625 \\
(0.606)\end{array}$ \\
\hline Rebase Economy & -0.330 & -0.331 & -0.331 & -0.314 \\
\hline
\end{tabular}




\begin{tabular}{|c|c|c|c|c|}
\hline & $(0.598)$ & $(0.600)$ & $(0.600)$ & $(0.575)$ \\
\hline \multirow[t]{2}{*}{ Bring back our girls } & -1.589 & -1.590 & -1.590 & -1.562 \\
\hline & $(1.055)$ & $(1.057)$ & $(1.057)$ & $(1.019)$ \\
\hline \multirow[t]{2}{*}{ Ebola crisis } & -0.594 & -0.567 & -0.567 & -0.520 \\
\hline & $(0.978)$ & $(0.902)$ & $(0.902)$ & $(0.864)$ \\
\hline \multirow[t]{2}{*}{$\mathrm{BH}$} & $2.962 * *$ & $2.935 * *$ & $2.935^{* *} *$ & 2.400 \\
\hline & $(1.405)$ & $(1.456)$ & $(1.456)$ & $(1.621)$ \\
\hline \multirow[t]{2}{*}{ AS } & -0.538 & -0.549 & -0.549 & -0.506 \\
\hline & $(0.625)$ & $(0.627)$ & $(0.627)$ & $(0.611)$ \\
\hline \multirow[t]{2}{*}{ Govt regains territory } & -2.337 & -2.335 & -2.335 & -2.497 \\
\hline & $(2.615)$ & $(2.616)$ & $(2.616)$ & $(2.728)$ \\
\hline \multirow[t]{2}{*}{ No change of territory } & $-5.373 * *$ & $-5.374 * *$ & $-5.374 * *$ & $-5.281 * *$ \\
\hline & $(2.463)$ & $(2.456)$ & $(2.456)$ & $(2.488)$ \\
\hline \multirow{2}{*}{$\begin{array}{l}\text { Headquarters/base } \\
\text { established }\end{array}$} & $-8.431 * * *$ & $-8.415^{* * *}$ & $-8.415 * * *$ & $-8.631 * * *$ \\
\hline & (3.031) & $(2.986)$ & $(2.986)$ & $(3.139)$ \\
\hline \multirow{2}{*}{$\begin{array}{l}\text { Non-violent activity } \\
\text { by conflict actor }\end{array}$} & $-7.983 * * *$ & $-7.974 * * *$ & $-7.974 * * *$ & $-8.023 * * *$ \\
\hline & $(2.761)$ & $(2.752)$ & $(2.752)$ & $(2.804)$ \\
\hline \multirow{2}{*}{$\begin{array}{l}\text { Non-violent transfer } \\
\text { of territory }\end{array}$} & $-8.274 * * *$ & $-8.264 * * *$ & $-8.264 * * *$ & $-8.382 * * *$ \\
\hline & $(2.910)$ & $(2.894)$ & $(2.894)$ & $(2.956)$ \\
\hline \multirow[t]{2}{*}{ Remote violence } & $-5.872 * *$ & $-5.870 * *$ & $-5.870 * *$ & $-5.753 * *$ \\
\hline & $(2.618)$ & $(2.610)$ & $(2.610)$ & $(2.629)$ \\
\hline \multirow[t]{2}{*}{ Riots/protests } & $-7.893 * * *$ & $-7.893 * * *$ & $-7.893 * * *$ & $-7.803 * * *$ \\
\hline & $(2.883)$ & $(2.875)$ & $(2.875)$ & $(2.898)$ \\
\hline Violence against & $-5.196^{*}$ & $-5.200 *$ & $-5.200^{*}$ & $-5.161^{*}$ \\
\hline \multirow{3}{*}{$\begin{array}{l}\text { civilians } \\
2011\end{array}$} & $(2.616)$ & $(2.610)$ & $(2.610)$ & $(2.648)$ \\
\hline & -1.151 & -1.149 & -1.149 & -1.088 \\
\hline & $(1.313)$ & $(1.311)$ & $(1.311)$ & $(1.244)$ \\
\hline \multirow[t]{2}{*}{2012} & $-1.976 *$ & $-1.973 *$ & $-1.973^{*}$ & $-1.904 *$ \\
\hline & $(1.129)$ & $(1.120)$ & $(1.120)$ & $(1.076)$ \\
\hline \multirow[t]{2}{*}{2013} & $-1.983 * * *$ & $-1.982 * * *$ & $-1.982 * * *$ & $-1.928 * * *$ \\
\hline & $(0.724)$ & $(0.719)$ & $(0.719)$ & $(0.691)$ \\
\hline \multirow{2}{*}{\multicolumn{2}{|c|}{$\begin{array}{l}\text { Media source included } \\
\text { date }\end{array}$}} & & & -1.096 \\
\hline & & & & $(0.822)$ \\
\hline \multirow{2}{*}{$\begin{array}{l}\text { Media source included } \\
\text { week }\end{array}$} & & & & 2.248 \\
\hline & & & & $(1.723)$ \\
\hline \multirow[t]{2}{*}{ Constant } & $9.131 * *$ & $9.132 * *$ & $9.132 * *$ & $10.02 * * *$ \\
\hline & $(3.451)$ & $(3.444)$ & $(3.444)$ & $(3.323)$ \\
\hline Observations & 13,604 & 13,604 & 13,604 & 13,604 \\
\hline R-squared & 0.050 & 0.050 & 0.050 & 0.053 \\
\hline
\end{tabular}

Notes: Robust standard errors in parentheses, with clustering at the level of administrative units. BH: Boko Haram. AS: Al Shabaab. Media precision of reported military attack rating: the most precise media sources include a specific date of the attack. The second most precise media sources include the specific week of the attack. ***Significant at 1 percent, **Significant at 5 percent, *Significant at 10 percent. 


\begin{tabular}{|c|c|c|c|c|c|}
\hline $\begin{array}{l}\text { Battle: Non-state } \\
\text { actor overtakes } \\
\text { territory }\end{array}$ & $\begin{array}{l}3.081 \\
(1.920)\end{array}$ & $\begin{array}{l}4.422^{*} \\
(2.412)\end{array}$ & $\begin{array}{l}4.635^{*} \\
(2.353)\end{array}$ & $\begin{array}{l}4.635^{*} \\
(2.353)\end{array}$ & $\begin{array}{r}4.214 * * \\
(1.950)\end{array}$ \\
\hline $\begin{array}{l}\text { Non-violent activity by } \\
\text { a conflict actor }\end{array}$ & $\begin{array}{c}0.578 \\
(1.802)\end{array}$ & $\begin{array}{l}2.416 \\
(2.235)\end{array}$ & $\begin{array}{l}2.382 \\
(2.132)\end{array}$ & $\begin{array}{l}2.382 \\
(2.132)\end{array}$ & $\begin{array}{l}2.025 \\
(1.752)\end{array}$ \\
\hline $\begin{array}{l}\text { Non-violent transfer } \\
\text { of territory }\end{array}$ & $\begin{array}{c}0.981 \\
(1.504)\end{array}$ & $\begin{array}{c}3.054 \\
(2.228)\end{array}$ & $\begin{array}{c}3.040 \\
(2.146)\end{array}$ & $\begin{array}{c}3.040 \\
(2.146)\end{array}$ & $\begin{array}{l}2.642 \\
(1.767)\end{array}$ \\
\hline Remote violence & $\begin{array}{l}3.777 * * \\
(1.825)\end{array}$ & $\begin{array}{l}5.762 * * * \\
(2.409)\end{array}$ & $\begin{array}{l}5.720 * * \\
(2.335)\end{array}$ & $\begin{array}{l}5.720 * * \\
(2.335)\end{array}$ & $\begin{array}{c}5.310 * * * * \\
(1.922)\end{array}$ \\
\hline $\begin{array}{l}\text { Violence against } \\
\text { civilians }\end{array}$ & $\begin{array}{l}3.652 \\
(2.250)\end{array}$ & $\begin{array}{l}5.538 * * \\
(2.688)\end{array}$ & $\begin{array}{l}5.476 * * \\
(2.626)\end{array}$ & $\begin{array}{l}5.476 * * \\
(2.626)\end{array}$ & $\begin{array}{l}5.103^{* *} \\
(2.231)\end{array}$ \\
\hline Year 2011 dummy & $\begin{array}{l}-2.605 \\
(2.168)\end{array}$ & $\begin{array}{l}-3.042 \\
(2.170)\end{array}$ & $\begin{array}{l}-3.050 \\
(2.162)\end{array}$ & $\begin{array}{l}-3.050 \\
(2.162)\end{array}$ & $\begin{array}{l}-3.146 \\
(2.247)\end{array}$ \\
\hline Year 2012 dummy & $\begin{array}{c}-4.231^{* * *} \\
(1.859)\end{array}$ & $\begin{array}{c}-4.852^{* * *} \\
(2.059)\end{array}$ & $\begin{array}{c}-4.871 * * \\
(2.047)\end{array}$ & $\begin{array}{c}-4.871 * * \\
(2.047)\end{array}$ & $\begin{array}{c}-4.955^{* *} \\
(2.113)\end{array}$ \\
\hline Year 2013 dummy & $\begin{array}{l}-2.348^{*} \\
(1.241)\end{array}$ & $\begin{array}{c}-3.050^{* * *} \\
(1.160)\end{array}$ & $\begin{array}{c}-3.060^{* * *} \\
(1.151)\end{array}$ & $\begin{array}{c}-3.060 * * \\
(1.151)\end{array}$ & $\begin{array}{c}-3.152 * * \\
(1.202)\end{array}$ \\
\hline $\begin{array}{l}\text { Media source included } \\
\text { date }\end{array}$ & & & & & $\begin{array}{l}-0.210 \\
(0.901)\end{array}$ \\
\hline $\begin{array}{l}\text { Media source included } \\
\text { week }\end{array}$ & & & & & $\begin{array}{c}-1.538 * * \\
(0.648)\end{array}$ \\
\hline BECE2014 & & $\begin{array}{l}2.936 \\
(2.871)\end{array}$ & $\begin{array}{l}0.963 * \\
(0.524)\end{array}$ & & \\
\hline Constant & $\begin{array}{l}-1.531 \\
(1.519)\end{array}$ & $\begin{array}{l}-2.050 \\
(1.234)\end{array}$ & $\begin{array}{l}-1.999 \\
(1.202)\end{array}$ & $\begin{array}{l}-1.999 \\
(1.202)\end{array}$ & $\begin{array}{l}-1.314 \\
(1.424)\end{array}$ \\
\hline Observations & 2,167 & 2,167 & 2,167 & 2,167 & 2,167 \\
\hline R-squared & 0.101 & 0.134 & 0.135 & 0.135 & 0.135 \\
\hline
\end{tabular}

Notes: Robust standard errors in parentheses, with clustering at the level of administrative units. BH: Boko Haram. AS: Al Shabaab. BECE: Basic Education Certificate Examination. Media precision of reported military attack rating: the most precise media sources include a specific date of the attack. The second most precise media sources include the specific week of the attack. *** Significant at 1 percent, **Significant at 5 percent, $*$ Significant at 10 percent. $* * * \mathrm{p}<0.01, * * \mathrm{p}<0.05, * \mathrm{p}<0.1$ 


\section{References}

- Adesoji, Abimbola 2010. "The Boko Haram Uprising and Islamic Revivalism in Nigeria/Die Boko-Haram-Unruhen und die Wiederbelebung des Islam in Nigeria.” Africa Spectrum, 45(2), 95-108.

- Acemoglu, Daron, Suresh Naidu, Pascual Restrepo, and James A. Robinson 2014. "Democracy, Redistribution and Inequality," Handbook of Income Distribution, 2, 1885-1966.

- Agbiboa, Daniel Egiegba 2015. "The social dynamics of the "Nigerian Taliban": fresh insights from the social identity theory." Social Dynamics 41(3), 415-437.

- American Political Science Association 2016. The American Political Science Association's Task Force on Political Violence and Terrorism (American Political Science Association. $<$ http://www.apsanet.org/politicalviolence>

- Armed Conflict Location \& Event Data Project 2014. "Conflict Trends Report, "No. 24, April 2014, http://www.acleddata.com/research-and-publications/conflict-trends-reports/.

- Banerjee, Abhijit V., and Sendhil Mullainathan 2008. "Limited attention and income distribution," American Economic Review: Papers and Proceedings, 98(2), 489-493.

- Bénabou, Roland 2008. "Ideology," Journal of the European Economic Association, 6(2-3), $321-352$.

- Blattman, Christopher, Julian C. Jamison and Margaret Sheridan. 2016. "Reducing Crime and Violence: Experimental Evidence from Cognitive Behavioral Therapy in Liberia.” American Economic Review, forthcoming.

- Bordalo, Pedro, Nicola Gennaioli and Andrei Shleifer. 2015. "Competition for Attention," Review of Economic Studies, 83(2), 481-513.

- Bushman, Brad J., and Roy F. Baumeister. 1998. “Threatened Egotism, Narcissism, SelfEsteem, and Direct and Displaced Aggression: Does Self-Love or Self-Hate Lead to Violence?," Journal of Personality and Social Psychology, 75(1), 219-229. 
- Filipe, Campante,and David Yanagizawa-Drott. 2015. "Does Religion Affect Economic Growth and Happiness? Evidence from Ramadan.” Quarterly Journal of Economics, 130(2), $615-658$.

- Cho, Jaeho, Michael P. Boyle, Heejo Keum, Mark D. Shevy, Douglas M. McLeod, Dhavan V. Shah and Zhongdang Pan (2003). "Media, terrorism, and emotionality: Emotional differences in media content and public reactions to the September 11th terrorist attacks." Journal of Broadcasting \& Electronic Media 47(3), 309-327.

- Crawford, Vincent P., and Joel Sobel 1982. "Strategic information transmission," Econometrica, 50(6), 1431-1451.

- Crenshaw, Martha. 1981. “The Causes of Terrorism,” Comparative Politics, 13(4), 379-399.

- Crowe, Sybil E. 1942. The Berlin West African Conference, 1884-1885. New York: Longmans, Green.

- Devarajan, Shantayanan. 2013. "Africa's statistical tragedy.” Review of Income and Wealth 59, S9-S15.

- Enders, W., and Sandler T. 2012. The Political Economy of Terrorism, 2nd ed.., Cambridge University Press, New York.

- Falkinger, Josef. 2008. "Limited Attention as a Scarce Resource in Information-Rich Economies," Economic Journal, 118(532), 1596-1620.

- Fernandez E. (Ed.). 2013. Treatments for anger in specific populations: Theory, application, and outcome. Oxford, England: Oxford University Press.

- Gartenstein-Ross, Daveed 2009. "The Strategic Challenge of Somalia's Al-Shabaab." Middle East Quarterly, Fall, 25-36.

- Gentzkow, Matthew and Emir Kamenica. 2016. "Competition in Persuasion," Review of Economic Studies, forthcoming. 
- Gentzkow, Matthew and Jesse Shapiro. 2011. "Ideological Segregation Online and Offline," Quarterly Journal of Economics, 126(4), 1799-1839.

- Global Peace Operations Review. 2011. “Somalia.” http://peaceoperationsreview.org/wpcontent/uploads/2014/10/2012_argpo_somalia_mr.pdf

- Harttgen, Kenneth, Stephan Klasen, and Sebastian Vollmer. 2013. "An African growth miracle? Or: what do asset indices tell us about trends in economic performance?" Review of Income and Wealth, 59, (2013): S37-S61.

- Helliwell, John F., Haifang Huang and Shun Wang. 2015. "The Geography of World Happiness" in eds. John Helliwell, Richard Layard and Jeffrey Sachs, 2015 World Happiness Report, Earth Institute, Columbia University/Canadian Institute for Advanced Research/Sustainable Development Solutions Network/Centre for Economic Performance/Emirates Competitive Council.

http://worldhappiness.report/wp-content/uploads/sites/2/2015/04/WHR15_Sep15.pdf

- Huffington Post. 2017. "Boko Haram Actually Kills More People In Terror Attacks Than ISIS.”

http://www.huffingtonpost.com/entry/boko-haram-isis_us_564cd890e4b00b7997f8c15d

- Jetter, Michael. 2016. "Blowing Things Up: The Effect of Media Attention on Terrorism." University of Western Australia Working Paper.

- Krueger, Alan B. 2007. What Makes a Terrorist: Economics and the Roots of Terrorism, (Princeton University Press, Princeton, NJ).

- Krueger, Alan B. and Jitka Malečková. 2009. "Attitudes and Action: Public Opinion and the Occurrence of International Terrorism,” Science, 325(5947), 1534-1536.

- Novaco R. W. 1976. The functions and regulation of the arousal of anger. The American Journal of Psychiatry, 133, 1124-1128 
- Sinead Lambe, Catherine Hamilton-Giachritsis, Emily Garner, and Julian Walker 2016. "The Role of Narcissism in Aggression and Violence A Systematic Review." Trauma, Violence and Abuse, 1-22.

- Lazarus, Paul O. and Tulika A. Saraf. 2015. "Social media fostering social good: a case of election monitoring in Nigeria," ICTD '15 Proceedings of the Seventh International Conference on Information and Communication Technologies and Development, Article No. 47, Singapore - May 15 - 18, 2015.

- Mahajan, Vijay. 2012. Africa Rising: How 900 Million African Consumers Offer More Than You Think (Prentice Hall, New Jersey).

- Manelici, Isabela. 2016. "Terrorism and the Value of Proximity to Public Transportation: Evidence from the 2005 London Bombings.” University of California, Berkeley Working Paper.

- Marchal, Roland. 2009. "A tentative assessment of the Somali Harakat Al-Shabaab." Journal of Eastern African Studies 3(3), 381-404.

- Michalopoulos, Stelios and Elias Papaioanno 2016. "The Long-Run Effects of the Scramble for Africa" American Economic Review, 106(7), 1802-1848

- Morf, Carolyn C., and Frederick Rhodewalt. 2001. "Unraveling the Paradoxes of Narcissism: A Dynamic Self-Regulatory Processing Model,” Psychological Inquiry, 12(4), 177-196.

- Mwangi, Oscar Gakuo. 2010. "The Union of Islamic Courts and security governance in Somalia." African Security Review, 19(1), 88-94.

- National Consortium for the Study of Terrorism and Responses to Terrorism. 2015. "American Terrorism Deaths Fact Sheet."

https://www.start.umd.edu/pubs/START_AmericanTerrorismDeaths_FactSheet_Oct2015.pdf

- Onuoha, Freedom C. 2010. "The Islamist challenge: Nigeria's Boko Haram crisis explained." African Security Review 19(2), 54-67. 
- Raleigh, Clionadh and Caitriona Dowd. 2016. Armed Conflict Location and Event Data Project (ACLED) Codebook 2016

http://www.acleddata.com/wp-content/uploads/2016/01/ACLED_Codebook_2016.pdf

- Ray, Debraj, and Joan Esteban. 2016. "Conflict and Development," Annual Reviews of Economics, forthcoming.

- Romano, Ann T. 1984. Terrorism: An Analysis of the Literature. Ph.D Dissertation, Fordham University.

- Ross, Jeffrey Ian. 1993. "Structural causes of oppositional political terrorism: Towards a causal model." Journal of Peace Research 30(3), 317-329.

- Schamborg S., and R. J. Tully. 2015. A systematic review of the effectiveness of anger management interventions among adult male offenders in secure settings. Archives of Forensic Psychology, 1, 28-54.

- Simon, Herbert A. 1971. "Designing Organizations for an Information-Rich World," in Martin Greenberger, Computers, Communication, and the Public Interest, Baltimore, MD: The Johns Hopkins Press.

- Verhoeven, Harry. 2009. "The self-fulfilling prophecy of failed states: Somalia, state collapse and the Global War on Terror," Journal of Eastern African Studies, 3, 405-425.

- Vidino, Lorenzo, Raffaello Pantucci and Evan Kohlmann. 2010. "Bringing Global Jihad to the Horn of Africa: al Shabaab, Western Fighters, and the Sacralization of the Somali Conflict," African Security, 3(4), 216-238.

- White House Office of the Press Secretary. 2015. "Statement by the President on the Shootings at Umpqua Community College, Roseburg, Oregon."

https://obamawhitehouse.archives.gov/the-press-office/2015/10/01/statement-presidentshootings-umpqua-community-college-roseburg-oregon 
- Young, Alwyn. 2012. "The African Growth Miracle,” Journal of Political Economy, 120(4), 696-739. 